Article

\title{
Petrography and Tectonic Provenance of the Cretaceous Sandstones of the Bredasdorp Basin, off the South Coast of South Africa: Evidence from Framework Grain Modes
}

\author{
Temitope Love Baiyegunhi ${ }^{1, *}$, Kuiwu Liu ${ }^{1, *}$, Oswald Gwavava ${ }^{1}$ and Christopher Baiyegunhi ${ }^{2}$ \\ 1 Department of Geology, University of Fort Hare, Private Bag X1314, Alice 5700, Eastern Cape Province, \\ South Africa; ogwavava@ufh.ac.za \\ 2 Department of Geology and Mining, University of Limpopo, Private Bag X1106, Sovenga 0727, \\ Limpopo Province, South Africa; christopher.baiyegunhi@ul.ac.za \\ * Correspondence: lovedestiny324@yahoo.com (T.L.B.); kliu@ufh.ac.za (K.L.)
}

Received: 8 May 2020; Accepted: 3 June 2020; Published: 28 August 2020

\begin{abstract}
The Cretaceous sandstones of the Bredasdorp Basin were investigated to recognize their composition, provenance, and tectonic setting. Ninety-two samples of sandstones from exploration wells E-AH1, E-AJ1, E-BA1, E-BB1, and E-D3 were investigated using both petrographic and X-ray diffraction (XRD) methods. Petrographic studies based on quantitative investigation of the detrital framework grain shows that the Bredasdorp sandstones chiefly consist of quartz (52.2-68.0\%), feldspar $(10.0-18.0 \%)$, and lithic fragments $(5.0-10.2 \%)$. These sandstones are mostly fine grained, moderately well-sorted, and subrounded to rounded. The modal composition data shows that the sandstones could be classified as subarkosic arenite and lithic arkose. Such a composition of the sandstones perhaps indicates the interplay of pulses of fast uplift of the source area and rapid subsidence of the Bredasdorp Basin, with subsequent periods of calmness within the transgressive-regressive sequence in a rift tectonic regime. The provenance ternary diagrams revealed that the sandstones are mainly of continental block provenances (stable shields and basement uplifted areas) and complemented by recycled sands from an associated platform. The tectonic provenance studies of Bredasdorp Basin revealed that the sandstones are typically rift sandstones and have undergone long-distance transport from the source area along the rift. In the regional context of the evolution of the Bredasdorp Basin, the results presented in this study inferred that the basin developed on a rift passive setting (trailing edge) of the stable continental margins.
\end{abstract}

Keywords: sandstone; classification; provenance; tectonic setting; Bredasdorp Basin

\section{Introduction}

The Bredasdorp Basin situated in the southeast of Cape Town and west-southwest of Port Elizabeth Figure 1 is a south-easterly trending rift basin that is characterized by half-graben structures. These half-grabens are mostly made up of the Cretaceous and Cenozoic rift to drift strata. The basin developed along with other sub-basins of the larger Outeniqua Basin, as a result of rift and drift activity during the break-up of the Gondwana supercontinent along the Agulhas-Falkland Fracture Zone [1]. The Bredasdorp Basin, which is located off the south coast of South Africa, containing mainly sandstones with subordinate mudrocks, was investigated to interpret the provenance. The use of a framework or detrital mineral composition to unravel the tectonic provenance of sandstones was first reported by [2] and has subsequently undergone significant modification [3,4]. Over the years, provenance studies of sandstone have shown that different rock types (i.e., sandstone) contain 
their own tectonic settings, which, when weathered, eroded, and re-deposited, will yield sandstones with specific compositional ranges [3,5]. Hence, clastic detrital constituents or components contain vital information on the provenance, and mode of transportation and deposition of the sediments, particularly after modification or alteration of the original detritus by diagenetic processes [6].

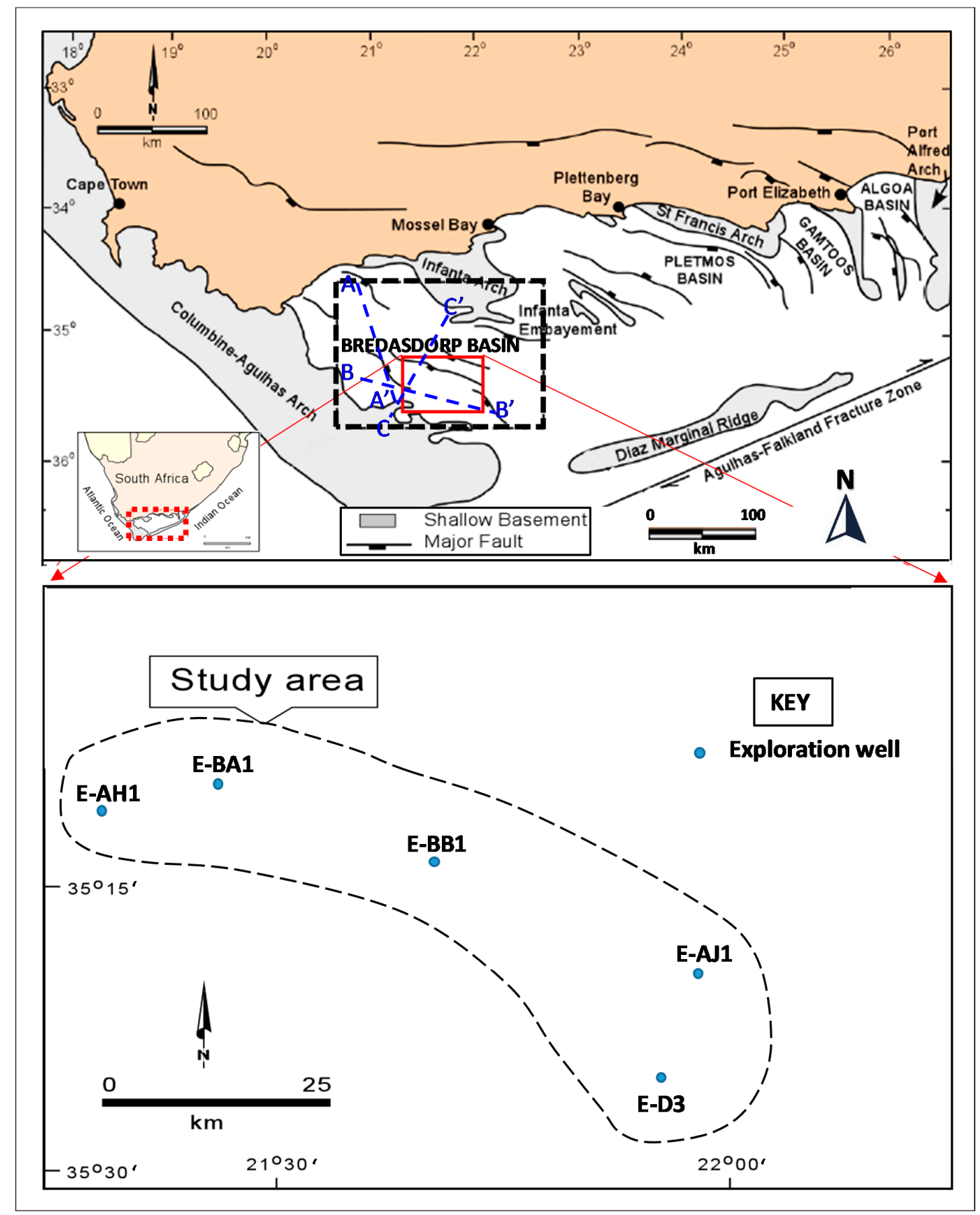

Figure 1. Map of the study area showing the distribution of the exploration wells across the Bredasdorp Basin (after [1]).

Modal composition analysis of detrital framework grains of sandstones is widely used for provenance studies [7] as well as whole rock geochemistry [8]. Hence, the mineralogical and chemical compositions of clastic sedimentary rocks are commonly used as the sensitive indicators of provenance, climate, and tectonism [9,10]. According to [7], the constituents of sediment are a function of the source 
composition, weathering, and transportation; therefore, sandstone framework grains (detrital modes) are connected to the tectonic settings of the provenance. Generally, siliciclastic rocks contain significant information or clues for unravelling the compositional tectonic setting as well as the development of the continental crust, which can be related to the depositional environment [11]. Several researchers, including [3,7,11-14], have investigated the relationship between the tectonic setting and sandstone petrography. The findings from the aforementioned investigations showed that petrographic studies of framework grains (detrital modes) of sandstones can be used to infer the tectonic provenance and associated depositional processes.

The sandstones of the Bredasdorp Basin have not previously been investigated in order to determine their composition and infer the tectonic provenance. Previous studies on the basin include those of [15-27] and they are mainly focused on sequence stratigraphy, petrophysical, and reservoir quality characterization of the basin. Despite all these efforts, only a few petrographic studies of the Bredasdorp sandstones have been reported and the few reported studies did not account for nor attempt to determine their tectonic provenance in the Bredasdorp Basin. In order to fill the gaps created, this study was undertaken to present new petrographic and modal analysis (point count) data of the sandstones from five offshore exploration wells (boreholes E-AH1, E-AJ1, E-BA1, E-BB1, and E-D3) located in the Bredasdorp Basin that penetrated the Agulhas Formation and Sundays River Formation Figure 2, Table 1. These data were used to characterize the detrital sediments, classify the sandstones, and deduce their tectonic provenance in the Bredasdorp Basin. Furthermore, the data presented in this study can serve as a base for petrographic and depositional correlations with other offshore sub-basins of the larger Outeniqua Basin.

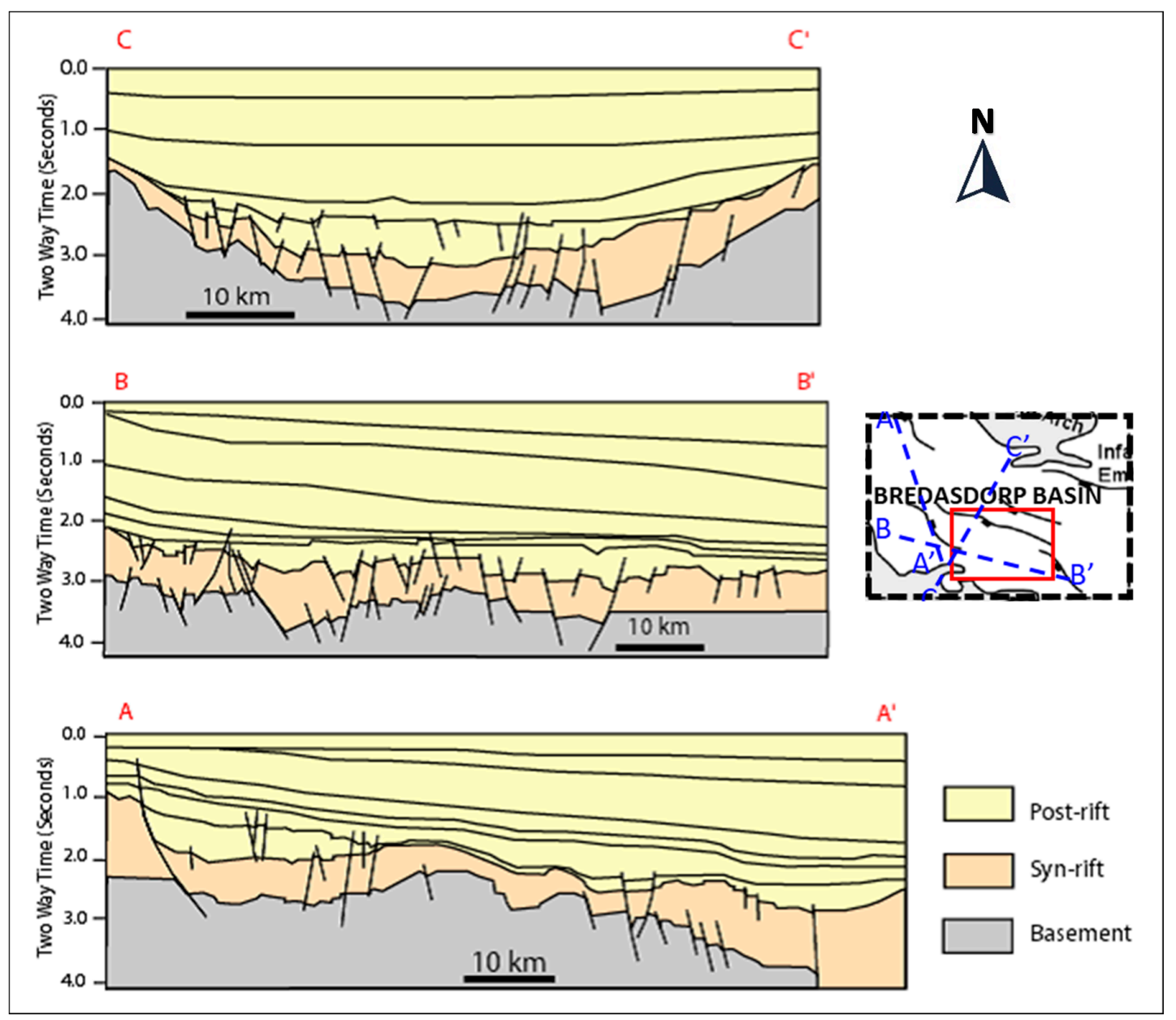

Figure 2. Three schematic cross-sections across the Bredasdorp Basin for profiles $A-A^{\prime}, B-B^{\prime}$, and $C-C^{\prime}$ in Figure 1 (after [20]). 
Table 1. Co-ordinates and total drilling depth of the studied exploration wells.

\begin{tabular}{cccccc}
\hline Wells/Borehole & E-AH1 & E-AJ1 & E-BA1 & E-BB1 & E-D3 \\
\hline Year of Drilling & $\mathbf{1 9 8 8}$ & $\mathbf{1 9 8 9}$ & $\mathbf{1 9 9 0}$ & $\mathbf{1 9 9 1}$ & $\mathbf{1 9 7 9}$ \\
Co-ordinates & $35^{\circ} 11^{\prime} 13.40^{\prime \prime} \mathrm{S}$ & $35^{\circ} 20^{\prime} 09.15^{\prime \prime} \mathrm{S}$ & $35^{\circ} 09^{\prime} 29.67^{\prime \prime} \mathrm{S}$ & $35^{\circ} 14^{\prime} 51.32^{\prime \prime} \mathrm{S}$ & $35^{\circ} 28^{\prime} 45.91^{\prime \prime} \mathrm{S}$ \\
Total Drilling Depth (m) & $21^{\circ} 08^{\prime} 37.07^{\prime \prime} \mathrm{E}$ & $21^{\circ} 58^{\prime} 37.45^{\prime \prime} \mathrm{E}$ & $21^{\circ} 28^{\prime} 31.19^{\prime \prime} \mathrm{E}$ & $21^{\circ} 41^{\prime} 41.088^{\prime \prime} \mathrm{E}$ & $21^{\circ} 56^{\prime} 16.16^{\prime \prime} \mathrm{E}$ \\
Depth of Sampling (m) & 3729 & 3490 & 3130 & 3320 & 3996 \\
No of Samples & $2471-2483$ & $2696-3043$ & $2828-2850$ & $2537-3294$ & $3261-3530$ \\
\hline
\end{tabular}

\section{Generalized Geology and Stratigraphy}

The Bredasdorp Basin is the westernmost sub-basin of the large Outeniqua Basin and it covers an area extent of approximately $18,000 \mathrm{~km}^{2}$ underneath the Indian Ocean along the southern coast of South Africa [22] (Figure 1). The western and eastern sides of the basin are bounded by the Columbine-Agulhas Arch (CAA) and the Infanta Arch (IA), respectively [16,25]. The CAA and IA are extended basement highs and they are made up of the Cape Supergroup granite and Precambrian (basement) metamorphic rocks. The Bredasdorp Basin was reported to have developed along the South African continental margin, underneath the Indian Ocean, due to extensional episodes during the initial stage of rifting in the late Jurassic-early Cretaceous [28]. As reported by [27], the basin underwent successions of structural distortion during the break-up of Gondwanaland as well as the continents that fall within the southern hemisphere. According to [26], the dextral trans-tensional stress or right-lateral shear movement that was produced along the Falkland-Agulhas Fracture Zone (AFFZ) occurred as a result of the separation of the Falkland Plateau from the Mozambique Ridge as well as the break-up of west Gondwana. The tectonic events initiated the development of normal faulting north of the AFFZ, resulting in the creation of graben and half-graben sub-basins (i.e., Bredasdorp Basin) [16]. The basin is principally filled-up with the late Jurassic and early Cretaceous syn-rift continental and marine sediments as well as the post Cretaceous and Cenozoic divergent rocks (rock found at divergent plate boundaries), mostly comprising of slanting or inclined half-graben structures.

Stratigraphically, the basin is made up of the Oxfordian-Recent stratigraphic column $[16,23]$ overlying the Cape Supergroup [18]. The stratigraphic column shows the occurrence of a syn-rift phase and post-rift or drift phase Figure 2 [17]. The syn-rift phase can be subdivided into the syn-rift I and syn-rift II sedimentation [17]. The syn-rift I sedimentation took place from the middle Jurassic up to the late Valanginian (Basement to 1At1) whereas the syn-rift II sedimentation occurred from the late Valanginian until the Hauterivian (1At1 to 6At1) [23] (Figure 2). In the northern part of the basin, the basal syn-rift deposits that occurred during the Kimmeridgian-late Valanginian are divided into four intervals (from base to top), namely the Lower Fluvial (LF), Lower Shallow Marine (LSM), Upper Fluvial (UF), and Upper Shallow Marine (USM) intervals. The abovementioned intervals underlie the Late Valanginian 1At1 regional unconformity [25] (Figure 3). The Lower Fluvial interval is made up of claystones, sandstones, and conglomerates deposited in alluvial fan and fluvial environments, representing an early graben fill [25]. The overlying Lower Shallow Marine interval consists of glauconitic fossiliferous sandstones and it indicates progradational beach deposits of "Portlandian" (Kimmeridgian) age, signifying the first marine incursion into the basin. The Upper Fluvial interval is made up of alluvial floodplain and meandering fluvial deposits, whereas the overlying Upper Shallow Marine interval is marked by the occurrence of massive glauconitic fossiliferous sandstones of the late Valanginian age. The authors of [25] reported that these massive glauconitic fossiliferous sandstones were deposited as transgressive beach facies along the northern and southern edges of the basin and extending into the neighboring or nearby sub-basins.

The syn-rift I succession is terminated by a regional 1At1 unconformity, separating the deep-marine sediments from the underlying Upper Shallow Marine sediments. This 1At1 unconformity signifies the beginning of a renewed rifting (synrift II) phase initiated due to early movement along the AFFZ at approximately $121 \mathrm{Ma}$ (Valanginian-Hauterivian boundary) [17]. The syn-rift II was later followed by the Transitional (early Drift) phase, which occurred during Hauterivian-early Aptian (6At1 to 13At1) 
(Figure 2). The Transitional (early Drift) phase was characterized by recurrent episodes of progradation and aggradation and it was mostly affected by tectonic events and eustatic sea-level changes [25]. This phase was considered as the first deep water deposits in the Bredasdorp Basin and they were deposited due to major subsidence of the basin as well as the increase of the water depth. On the other hand, the late drift phase trailed a major marine regression in the Bredasdorp Basin during the early Aptian. This regression event resulted in a major erosion, which is marked by the 13At1 unconformity. The erosion period is followed by a marine transgression, which carried and deposits organic-rich claystone in the basin under an anoxic condition [18]. The onset of the late drift phase is manifested or noted by the 14At1 mid-Albian unconformity Figure 2, which marks the beginning of the active thermally driven subsidence when the Columbine-Agulhas Arch was cleared by the trailing edge of the Falkland Plateau in the Late Albian $[19,25]$.

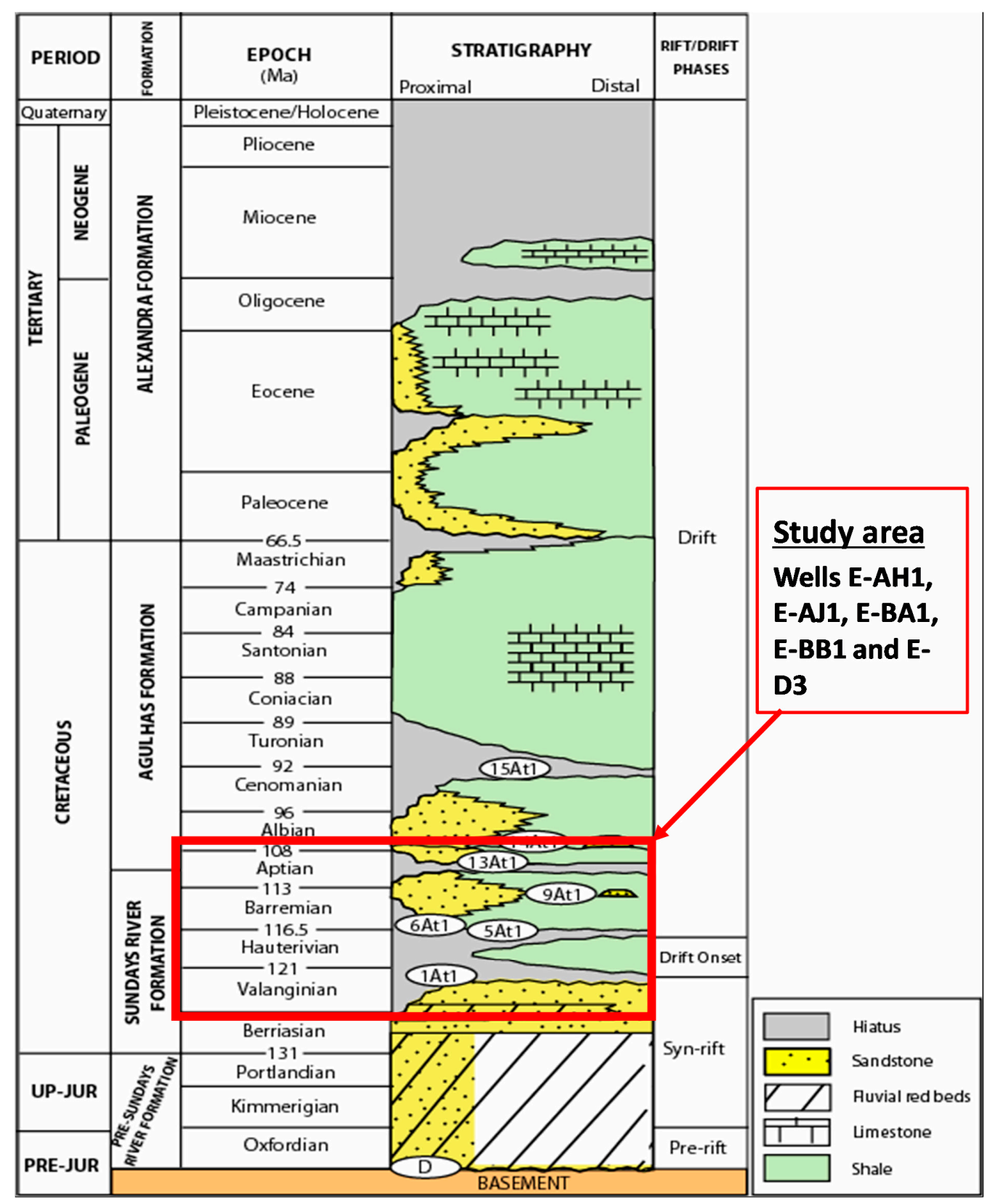

Figure 3. Proximal and distal stratigraphy of the Bredasdorp Basin (after [21]). 


\section{Materials and Methods}

Modal composition and textural analyses were performed on approximately 150 thin sections of the 92 representative sandstone samples collected from exploration wells E-AH1, E-AJ1, E-BA1, E-BB1, and E-D3 in the study area (Figure 1, Table 1). Thin sections of the sandstones were prepared and studied under the petrographic microscope. The roundness of the studied samples was quantified based on the visual comparison chart of [29]. The chart allows a quick and easy method of determining the roundness (roundness classes: Very angular, angular, subangular, subrounded, rounded, and well rounded) of a two-dimensional particle shape (Table 2), although the comparisons can be subjective. For the grain size analysis, a minimum of 500 grains were measured (by means of an ocular with a millimeter scale) per thin section using the standard method of measuring the grain's longest axis as proposed by [30-32]. Thereafter, the frequencies of grain size distributions were computed, and the Udden-Wentworth grade scale was used to determine the grain size classes [33]. For calculating the mean grain size and standard deviation, the graphic method according to $[34,35]$ was used.

Table 2. Textural parameters and their corresponding verbal terms [35].

\begin{tabular}{llllllll}
\hline Phi mean & $0.00-1.00$ & $1.00-2.00$ & $2.00-3.00$ & $3.00-4.00$ & & & \\
\hline $\begin{array}{l}\text { Grain Size } \\
\text { Phi Standard }\end{array}$ & Coarse & Medium & Fine & Very fine & & & \\
$\begin{array}{l}\text { Deviation } \\
\text { Verbal Sorting }\end{array}$ & $<0.35$ & $0.35-0.50$ & $0.50-0.71$ & $0.71-1.00$ & $1.00-2.00$ & $2.00-4.00$ & $>4.00$ \\
very well sorted & well sorted & $\begin{array}{l}\text { moderately well } \\
\text { sorted }\end{array}$ & $\begin{array}{l}\text { moderately } \\
\text { sorted }\end{array}$ & poorly sorted & $\begin{array}{l}\text { very poorly } \\
\text { sorted }\end{array}$ & $\begin{array}{l}\text { extremely } \\
\text { poorly sorted }\end{array}$ \\
\hline
\end{tabular}

For the modal composition analysis, at least 500 points were counted per thin section following the procedures recommended by [3,7]. An Olympus BX51 microscope with an inbuilt Olympus DP72 digital camera was used to analyze each of the thin sections in line with the Gazzi-Dickinson's traditional point-counting technique. For each thin section, an equally spaced counting grid was deployed to go across the thin section, and the framework grains as well as the matrix were counted under the grid nodes. The grids were spaced in a way that each grid go beyond the grain size to avoid counting a particular grain more than once. The framework components were determined using the methods of $[3,5]$. The minerals making up the sandstones were categorized into quartz (monocrystalline and polycrystalline), feldspar, lithic fragments, mica, cement, and matrix. The total quartz-feldspar-lithic fragments (Qt-F-L) counts as per Gazzi-Dickinson were used in the standard diagrams for sandstone classification and nomenclature. To classify the sandstones, the framework parameters of the detrital modes in the sandstones were recalculated to $100 \%$ and ternary diagrams of Qt-F-L were plotted. In addition, 30 sandstone samples were also analyzed by X-ray diffraction (XRD) to determine the mineral compositions. The XRD analysis was carried out using the backloading preparation method. The diffractograms were obtained by means of a Malvern Panalytical Aeris diffractometer with a PIXcel detector and fixed slits with Fe-filtered $\mathrm{Co}-\mathrm{K} \alpha$ radiation. The phases were identified using X'Pert Highscore plus software while the relative phase amounts (weight $\%$ ) were estimated using the Rietveld method.

\section{Results and Discussion}

\subsection{Sandstone Texture}

The studied sandstones are generally fine to medium grained and moderately sorted to moderately well sorted Figures 4 and 5. The textural characteristics of the sandstones is presented in the supplementary data (Table S1). Specifically, borehole E-AH1 consists mostly of massive, well sorted, fine- to medium-grained glauconitic sandstone and claystone with minor siltstone interbeds. The claystones are characterized by near-horizontal bedding and sediment injection features (sandstone into claystone) near the contacts with the sandstones. Borehole E-AJ1 is made up of claystones and siltstones with occasional interbedded sandstones. The sandstones in borehole E-AJ1 are generally massive (structureless), fine to medium grained, and contain abundant glauconite and 
are moderately well sorted. A distinctive feature in borehole E-AJ1 is the occurrence of stylolites, which are seen as irregular, undulatory, and coarsely sutured horizontal features and less commonly as finely sutured regular vertical to sub-vertical fractures. Borehole E-BA1 comprises mostly of massive moderately well-sorted, fine- to medium-grained glauconitic sandstone with minor claystone and siltstone. The sandstone is slightly porous, light brownish-grey with very fine to medium, well-sorted subangular grains. In addition, it is non-calcareous, slightly glauconitic, and slightly pyritic and contains green lithic fragments. The sandstone in borehole E-BB1 is mostly well sorted, fine grained, very lithic (metaquartzite clasts), glauconitic, and slightly shelly and carbonaceous. In borehole E-D3, the sandstones are massive, moderately sorted, medium grained, and slightly glauconitic. In general, the roundness of the grains in the studied sandstone samples vary from subangular to rounded and the sphericity ranges from low to high (mostly low; oblong grains). The grain packing is irregular, showing both fairly packed and tightly packed grains. However, in most cases, the grains are moderately tight. Furthermore, the grain contact patterns vary from point contact to sutured contact, but predominantly long and concavo-convex contacts. The sandstone grains are often cemented or supported by clay matrix; however, some are grain supported. The change in grain size in the vertical succession indicates both regressive and transgressive conditions, although the transgressive conditions tend to dominate.

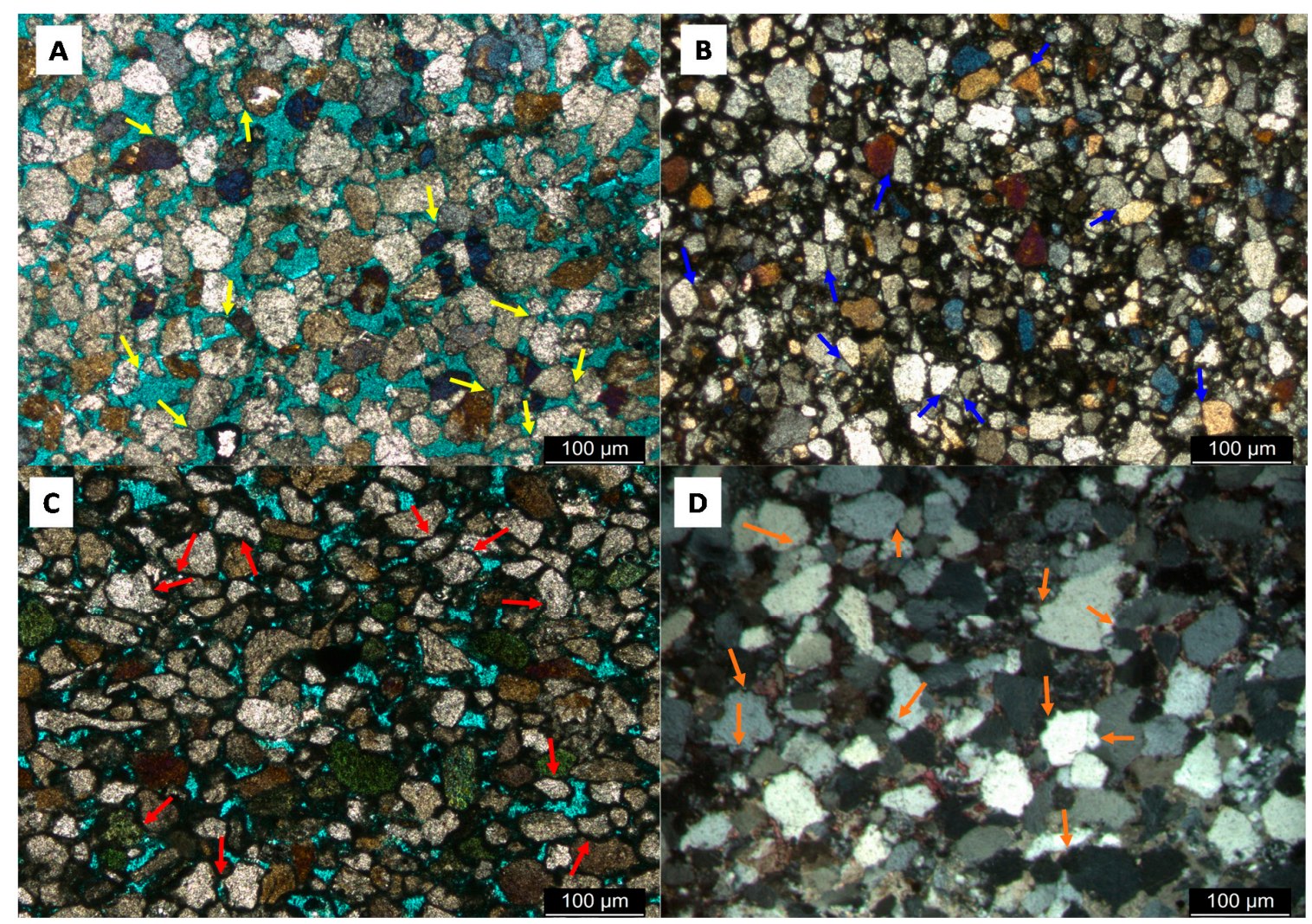

Figure 4. Photomicrograph of the Bredasdorp sandstone under cross-polarized light (XPL) showing different grain to grain contact. (A-D) shows point (yellow arrows) in borehole E-AH1 and long (blue arrows) in borehole E-AJ1, convano-convex (red arrows) in borehole E-BA 1, and sutured (brown arrows) grain contacts in borehole E-D3, respectively. 


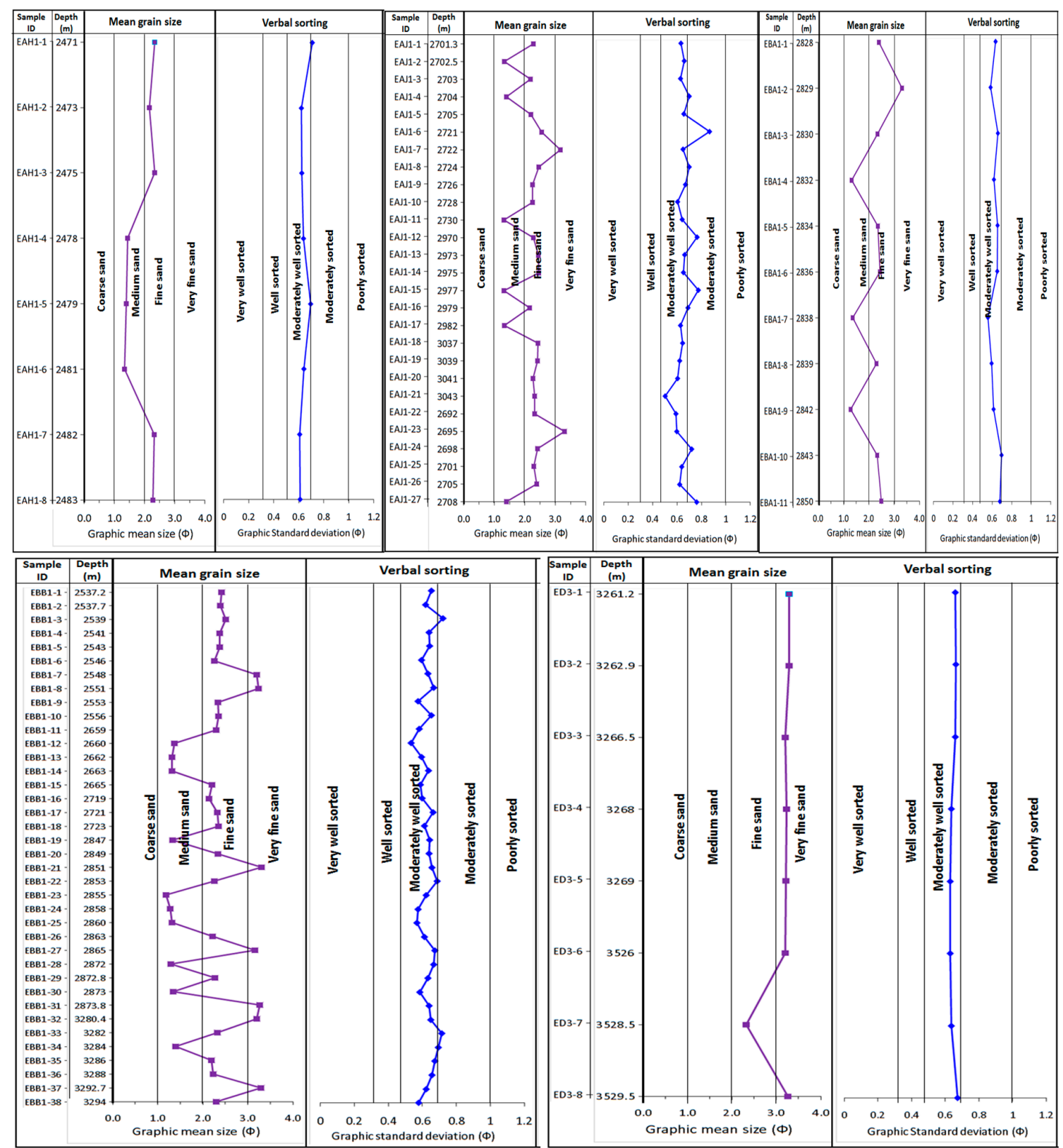

Figure 5. Downhole plot of the textural parameters (graphic mean and sorting) for the Cretaceous sandstones from the boreholes EAH1, E-AJ1, E-BA1, E-BB1, and E-D3.

\subsection{Sandstone Petrography}

The studied sandstones are made up of framework grains, accessory minerals, matrix, cement, and pores. The framework minerals are quartz, feldspar, lithic fragments, and glauconite, while the accessory minerals are mica (biotite and muscovite), zircon, and rutile. The matrix is mostly clay minerals and minor detrital silts, while the precipitated cements (authigenic minerals) are quartz cement, carbonate (calcite) cement, glauconite cement, and authigenic clay mineral cement.

\subsubsection{Quartz}

The quartz grains are usually subangular to rounded and constitute about $52.2-68.0 \%$ of the framework grains. The quartz occurs as both monocrystalline quartz $(\mathrm{Qm})$ and polycrystalline quartz (Qp) grains and often exhibits undulose and planar extinctions. The monocrystalline quartz (Qm) dominates, comprising about $97.04 \%$ (average) of the total quartz grains in the sandstones Table 3 . The quartz grains are sometimes fractured (cracked) and have dark boundaries or edges. The cracking 
or fracturing of the grains could be due to alteration. Furthermore, some of the quartz grains have an euhedral crystal form with overgrowth parts Figure 6a.

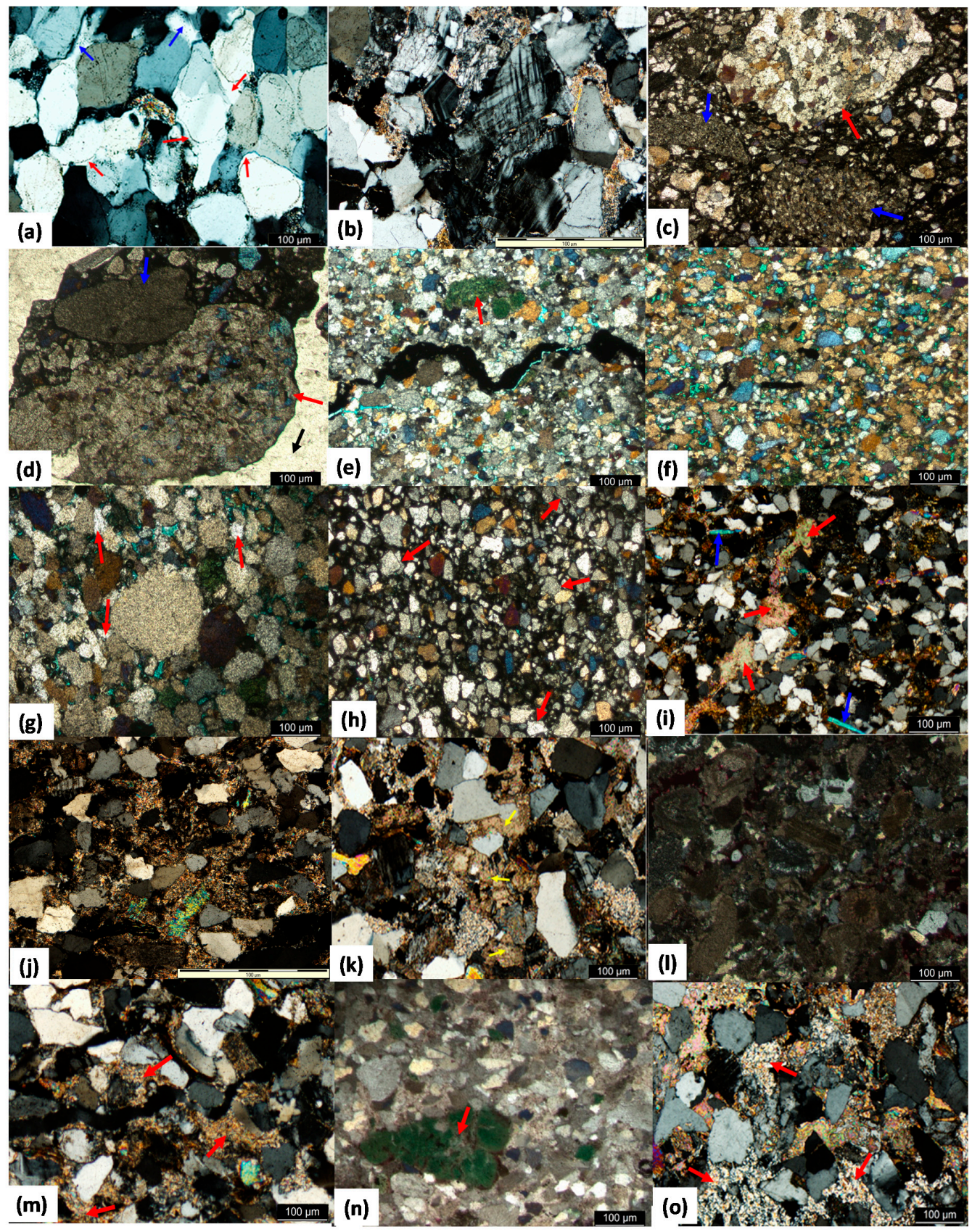

Figure 6. Photomicrograph of sandstone under cross-polarized light (XPL) showing (a) Authigenic quartz cement (blue arrows) and quartz overgrowths (red arrows) in borehole E-D3; (b) Albitization in borehole E-AH1; (c) Sedimentary lithic fragment (red arrow) and metamorphic lithic fragment (blue arrows) in borehole E-AH1; (d) Sedimentary lithic fragment (red arrow) and metamorphic lithic fragment (blue arrows) in borehole E-AH1; (e,f) Detrital glauconite and glauconite pellets in borehole E-AJ1; (g) Fine granular quartz cement (red arrows) in borehole E-AH1; (h) quartz overgrowths (red arrows) in borehole E-AJ1; (i) Calcite cement and mica flakes (blue arrows) in borehole E-BB1; (j) Mica in clay matrix in borehole E-BA1; (k) Calcite cement (yellow arrows); (1) Bioclasts (brownish colored) in borehole E-D3; (m) Partial replacement of feldspar by clay matrix (red arrows) in borehole E-AH1; (n) Partial replacement of feldspar and matrix by glauconite (red arrows) in borehole E-AJ1; (o) Partial replacement of feldspar by clay minerals (red arrows) in borehole E-BB1. 
Table 3. Mineralogical composition of the studied sandstone samples from XRD.

\begin{tabular}{|c|c|c|c|c|c|c|c|c|c|c|c|c|c|c|}
\hline Borehole & $\begin{array}{l}\text { Depth } \\
\text { (m) }\end{array}$ & $\begin{array}{c}\text { Quartz } \\
(\%)\end{array}$ & $\begin{array}{c}\text { Pyrite } \\
(\%)\end{array}$ & $\begin{array}{c}\text { Muscovite } \\
(\%)\end{array}$ & $\begin{array}{c}\text { Kaolinite } \\
(\%)\end{array}$ & $\begin{array}{l}\text { Plagioclase } \\
(\%)\end{array}$ & $\begin{array}{c}\text { Glauconite } \\
(\%)\end{array}$ & $\begin{array}{c}\text { Rutile } \\
(\%)\end{array}$ & $\begin{array}{c}\text { Dolomite } \\
(\%)\end{array}$ & $\begin{array}{c}\text { Calcite } \\
(\%)\end{array}$ & $\begin{array}{c}\text { Chlorite } \\
(\%)\end{array}$ & $\begin{array}{l}\text { Microcline } \\
(\%)\end{array}$ & $\begin{array}{c}\text { Smectite } \\
(\%)\end{array}$ & $\begin{array}{l}\text { Illite } \\
(\%)\end{array}$ \\
\hline \multirow{5}{*}{ E-AH1 } & 2471 & 56.07 & 2.10 & 5.80 & 13.60 & 6.10 & 4.15 & 0.00 & 0.40 & 9.40 & 0.10 & 1.32 & 0.60 & 0.50 \\
\hline & 2475 & 67.63 & 0.91 & 1.22 & 4.09 & 7.30 & 1.73 & 0.03 & 0.30 & 12.80 & 0.60 & 1.65 & 0.04 & 1.60 \\
\hline & 2478 & 69.36 & 1.02 & 0.98 & 7.40 & 8.90 & 0.65 & 0.11 & 0.16 & 6.40 & 0.34 & 4.54 & 0.12 & 0.00 \\
\hline & 2481 & 68.25 & 0.40 & 3.54 & 3.98 & 9.23 & 1.77 & 0.18 & 0.28 & 7.90 & 0.61 & 3.73 & 0.11 & 0.01 \\
\hline & 2483 & 67.38 & 0.32 & 2.19 & 5.32 & 9.72 & 1.98 & 0.05 & 0.21 & 9.43 & 0.39 & 2.13 & 0.32 & 0.54 \\
\hline \multirow{7}{*}{ E-AJ1 } & 2703 & 73.72 & 0.20 & 1.09 & 4.02 & 8.30 & 0.11 & 0.10 & 0.60 & 9.04 & 0.30 & 2.11 & 0.10 & 0.31 \\
\hline & 2721 & 68.51 & 0.21 & 1.20 & 5.01 & 9.22 & 1.98 & 0.10 & 0.70 & 10.4 & 0.80 & 1.69 & 0.01 & 0.20 \\
\hline & 2726 & 69.41 & 0.30 & 1.00 & 1.60 & 10.24 & 0.58 & 0.50 & 2.40 & 10.9 & 1.30 & 1.34 & 0.01 & 0.40 \\
\hline & 2730 & 63.50 & 0.09 & 5.60 & 10.40 & 11.10 & 0.19 & 0.40 & 0.20 & 7.10 & 0.20 & 1.11 & 0.07 & 0.00 \\
\hline & 2970 & 71.50 & 0.20 & 5.90 & 3.70 & 12.80 & 1.31 & 0.10 & 0.07 & 3.00 & 0.30 & 0.75 & 0.20 & 0.30 \\
\hline & 2982 & 69.71 & 0.61 & 4.70 & 6.60 & 14.54 & 0.66 & 0.32 & 0.20 & 1.82 & 0.11 & 0.43 & 0.20 & 0.22 \\
\hline & 3039 & 68.49 & 0.40 & 3.22 & 5.09 & 12.11 & 0.91 & 0.62 & 0.32 & 5.43 & 1.01 & 2.11 & 0.10 & 0.32 \\
\hline \multirow{5}{*}{ E-BA1 } & 2828 & 63.69 & 5.90 & 1.50 & 4.20 & 10.1 & 0.27 & 0.25 & 1.80 & 7.10 & 2.70 & 1.61 & 0.07 & 0.81 \\
\hline & 2832 & 68.79 & 0.30 & 2.17 & 3.70 & 14.5 & 0.22 & 0.11 & 0.06 & 8.11 & 0.55 & 1.42 & 0.06 & 0.00 \\
\hline & 2838 & 69.44 & 0.25 & 1.74 & 7.09 & 8.54 & 0.47 & 0.17 & 0.18 & 10.20 & 0.14 & 1.58 & 0.15 & 0.06 \\
\hline & 2843 & 61.91 & 0.65 & 2.01 & 6.77 & 9.30 & 0.33 & 0.30 & 0.05 & 16.80 & 0.27 & 1.27 & 0.21 & 0.15 \\
\hline & 2850 & 61.77 & 0.71 & 1.78 & 5.32 & 13.4 & 1.72 & 0.16 & 0.19 & 12.90 & 0.31 & 1.01 & 0.13 & 0.51 \\
\hline \multirow{9}{*}{ E-BB1 } & 2539 & 60.68 & 4.40 & 13.3 & 6.20 & 10.6 & 0.60 & 0.30 & 0.03 & 0.40 & 2.80 & 0.70 & 0.01 & 0.00 \\
\hline & 2548 & 60.09 & 2.52 & 2.66 & 6.98 & 9.80 & 0.12 & 0.11 & 0.01 & 13.50 & 1.22 & 2.77 & 0.10 & 0.11 \\
\hline & 2556 & 71.39 & 1.73 & 4.13 & 4.65 & 10.30 & 0.74 & 0.06 & 0.06 & 5.02 & 0.92 & 0.89 & 0.01 & 0.09 \\
\hline & 2662 & 70.39 & 1.88 & 4.21 & 4.73 & 9.55 & 0.38 & 0.19 & 0.21 & 4.17 & 1.05 & 3.18 & 0.04 & 0.01 \\
\hline & 2721 & 63.97 & 0.92 & 2.76 & 6.23 & 14.70 & 0.24 & 0.15 & 0.04 & 7.74 & 1.44 & 1.22 & 0.12 & 0.45 \\
\hline & 2849 & 67.6 & 0.21 & 2.11 & 4.86 & 15.20 & 0.06 & 0.04 & 0.09 & 6.90 & 0.76 & 1.43 & 0.03 & 0.72 \\
\hline & 2863 & 65.18 & 0.76 & 1.96 & 7.89 & 13.01 & 0.71 & 0.08 & 0.14 & 8.01 & 0.69 & 1.02 & 0.12 & 0.45 \\
\hline & 3284 & 70.01 & 0.33 & 1.48 & 5.21 & 8.90 & 0.40 & 0.02 & 0.22 & 11.74 & 0.44 & 1.04 & 0.01 & 0.22 \\
\hline & 3294 & 67.37 & 0.53 & 3.01 & 6.04 & 11.80 & 0.53 & 0.61 & 0.52 & 8.24 & 0.81 & 0.54 & 0.02 & 0.00 \\
\hline \multirow{4}{*}{ E-D3 } & 3261 & 68.43 & 1.00 & 2.50 & 5.10 & 10.60 & 0.44 & 0.50 & 0.60 & 7.13 & 0.70 & 2.68 & 0.12 & 0.21 \\
\hline & 3269 & 65.3 & 0.20 & 6.60 & 7.10 & 9.50 & 0.52 & 0.50 & 0.30 & 5.30 & 2.12 & 1.05 & 0.02 & 0.17 \\
\hline & 3526 & 67.55 & 0.30 & 3.44 & 6.04 & 12.30 & 1.08 & 0.27 & 0.24 & 4.26 & 1.68 & 2.43 & 0.01 & 0.42 \\
\hline & 3529 & 70.84 & 0.19 & 2.81 & 5.37 & 11.01 & 1.25 & 0.22 & 0.07 & 6.21 & 0.42 & 0.86 & 0.31 & 0.44 \\
\hline
\end{tabular}




\subsubsection{Feldspar}

The feldspar grains often range from subangular to subrounded and constitute about $10.0-18.0 \%$ of the framework grains. The observed feldspar types include orthoclase and microcline (alkali feldspar) and albite (plagioclase feldspar) (Figure 6b), with orthoclase being the most dominant. Occasionally, the feldspar grains are cloudy and patchy and have brown coatings on the grains. The feldspar grains occur as in both twinned and untwinned forms, although in most cases, no visible twining features are present. Some of the feldspar grain are fractured or cracked, and in a few instances, the feldspar grains (i.e., orthoclase or microcline) are partially altered to clay minerals (i.e., kaolinite). The partial dissolution of feldspar is also observed, hence leading to the formation of secondary porosity.

\subsubsection{Lithic Fragment}

The lithic fragments constitute about $5.0-10.2 \%$, averaging $7.8 \%$ of the framework grains. The observed lithic fragments often occur as mudrocks in a clay matrix (sedimentary lithic fragment) and clasts of sutured quartz grains with no matrix (metamorphic lithic fragment) Figure $6 \mathrm{c}, \mathrm{d}$. The sedimentary lithic fragments (fragments of sandstone and mudrock) constitute a greater proportion of the total lithic fragments.

\subsubsection{Glauconite}

The glauconite in the Bredasdorp sandstones is seen in the form of pellets, cement, and tiny grains squeezed between grains and in pore spaces Figure 6e,f. Quantitatively, the glauconites range from about $0.4-5.6 \%$, averaging $2.1 \%$ of the overall composition. The glauconite pellets are subrounded, elliptical, discoid, and mammillary in shape, ranging from 0.3 to $1.6 \mathrm{~mm}$ in size. The smaller pellets are mostly angular and elliptical in shape while the larger pellets are subrounded with a spheroidal to oval shape. The initial process of glauconitization of the detrital K-feldspars is seen in the form of small blebs along the grain boundaries, cleavage planes, and fractures until the feldspar is completely replaced. Generally, the glauconite grains and pellets are mostly formed as a result of glauconitization/replacement of feldspars, muscovite, and clay minerals. These glauconites have a light green color under plane-polarized light whereas under cross-polarized light, they exhibit high interference color ranging from third-order green to dark green color. Occasionally, the glauconite pellets are partially overgrown by quartz cement or partially dissolved in pores. Sometimes, there are black materials (speckles) on the glauconite grain surface, which could be a leftover or relic of hydrocarbons that passed through the glauconite.

\subsubsection{Matrix and Cement}

The matrix and cement serve as binding materials around larger or framework grains. The matrix constitutes about $3.2-13.8 \%$, whereas the cement constitutes between 1.8 and $10.0 \%$ of the overall composition. The matrix or groundmass is mostly clay minerals and they are either detrital or formed diagenetically. The diagenetic matrix minerals are thought to have been formed due to the alteration and precipitation of the framework grains, in addition to the recrystallization of other matrix minerals. On the other hand, the cements that bind the framework grains together are predominantly quartz, calcite, glauconite, dolomite, and authigenic clay mineral cements Figure $6 \mathrm{~g}-\mathrm{o}$. The quartz cement occurs primarily as pore filling and overgrowths around detrital quartz grains. The carbonate cements (calcite and dolomite) often show patchwork cleavage and they are seen between the grains, in pores (pore filling), and as grain coatings. The carbonate cements have pastel colors under XPL and are clear or plain under PPL, whereas the dolomite cements are pale green in color under XPL and are clear under PPL. The glauconite minerals occur as a pore-filling matrix. The authigenic clay minerals are the main cementing materials in the sandstones and they occur as pore-filling and pore-lining rim cement. 


\subsubsection{Accessory Minerals}

The observed accessory minerals in the sandstones are muscovite, biotite, zircon, and rutile, constituting about $0.1-1.0 \%$ of the overall composition. The muscovite occurs more frequently than others accessory minerals Figure 6i,j. In a few instances where muscovite and/or biotite are present, they occur as specks or bent flakes in the matrix. The bending of the mica flakes is a result of deformation.

\subsection{Mineralogy and Modal Composition}

The XRD analysis shows that the most abundant minerals include quartz (56.07-73.72\%) and plagioclase (6.10-14.50\%), while the dominant clay mineral is kaolinite (1.60-13.60\%) (Table 3). Quartz, feldspar, illite, and muscovite were formed as a result of recrystallization, whereas kaolinite and glauconite were formed through the dissolution of K-feldspar. Furthermore, kaolinite and glauconite were also seen as having replaced muscovite grains.

\section{Interpretation}

\subsection{Petrography and Mineralogy}

The sandstones of the Bredasdorp Basin are mainly made up of quartz, feldspar (mostly K-feldspar), lithic rock fragments, glauconite, muscovite, matrix, and cement. The percentages of quartz, feldspar, and lithic fragments vary between 52.2 and $68.8 \%, 10.0$ and $18.0 \%$, and 5.0 and $10.2 \%$, respectively Table 4. The average percentages and characteristics of the quartz and feldspar grains in the Bredasdorp sandstones indicate igneous, metamorphic, and pre-existing sedimentary rock provenances. This assumption is supported by general variation in the comparative abundance of the diverse types of the quartz and feldspar grains. Both monocrystalline $(\mathrm{Qm})$ and polycrystalline quartz (Qp) occur, perhaps suggesting derivation from both igneous and metamorphic sources. In accordance to the $[34,35]$ genetic and empirical classification of the quartz types, monocrystalline quartz grains are mostly plutonic, while polycrystalline quartz are recrystallized and stretched metamorphic types. The dominance of monocrystalline quartz grains indicates that the sandstones were mostly derived from a granitic source [36]. As reported by [37], these abundant monocrystalline grains in the sandstone samples could have been formed due to the disaggregation of original polycrystalline quartz grain during long-distance transport from the metamorphic source. Additionally, some of the polycrystalline quartz grains have two or more crystals with straight to slightly curved intercrystalline boundaries, signifying that the Bredasdorp sandstones were sourced from plutonic igneous rocks [38]. The presence of strained and unstrained quartz grains indicates that some of the strain was inherited from the source area, possibly indicating a granitic and/or metamorphic source for the quartz grains [39]. Additionally, some of the monocrystalline quartz grains exhibit undulatory extinction, indicative of metamorphic and pre-existing sedimentary rocks in the provenance [38]. The low percentages of feldspar and lithic fragments in the sandstones favor a cratonic source and mature transport regime [40]. The relative abundance of mica in the sandstones, perhaps of mafic igneous rocks or mica schists of high-grade metamorphism.

Table 4. Modal compositions of the sandstones from the Bredasdorp Basin.

\begin{tabular}{|c|c|c|c|c|c|c|c|c|c|c|c|c|c|c|c|c|}
\hline \multirow{2}{*}{ Borehole } & \multirow{2}{*}{$\begin{array}{c}\text { Depth } \\
\text { (m) }\end{array}$} & \multirow{2}{*}{$\begin{array}{c}\mathrm{Qt} \\
(\%)\end{array}$} & \multirow{2}{*}{$\begin{array}{l}\text { Qm } \\
(\%)\end{array}$} & \multirow{2}{*}{$\begin{array}{l}\text { Qp } \\
(\%)\end{array}$} & \multirow{2}{*}{$\begin{array}{c}F \\
(\%)\end{array}$} & \multirow{2}{*}{$\begin{array}{c}\mathrm{L} \\
(\%)\end{array}$} & \multirow{2}{*}{$\begin{array}{l}\text { GL } \\
(\%)\end{array}$} & \multirow{2}{*}{$\begin{array}{l}\text { Acc } \\
(\%)\end{array}$} & \multirow{2}{*}{$\begin{array}{l}\text { Cmt } \\
(\%)\end{array}$} & \multirow{2}{*}{$\begin{array}{l}\text { Mx } \\
(\%)\end{array}$} & \multicolumn{3}{|c|}{ QmFLt (\%) } & \multicolumn{3}{|c|}{ QtFL (\%) } \\
\hline & & & & & & & & & & & Qm & F & Lt & Qt & F & L \\
\hline \multirow{8}{*}{ E-AH1 } & 2471.0 & 59.0 & 57.6 & 1.4 & 13.4 & 7.4 & 4.2 & 0.2 & 3.8 & 12.0 & 72.2 & 16.8 & 11.0 & 73.9 & 16.8 & 9.3 \\
\hline & 2473.0 & 52.2 & 52.0 & 0.2 & 13.0 & 9.2 & 4.4 & 1.0 & 6.4 & 13.8 & 69.9 & 17.5 & 12.6 & 70.2 & 17.5 & 12.4 \\
\hline & 2475.0 & 58.8 & 56.0 & 2.8 & 14.2 & 5.8 & 5.0 & 0.3 & 6.4 & 9.5 & 71.1 & 18.0 & 10.9 & 74.6 & 18.0 & 7.4 \\
\hline & 2478.0 & 56.2 & 53.8 & 2.4 & 13.6 & 5.2 & 4.0 & 0.4 & 7.0 & 13.6 & 71.7 & 18.1 & 10.1 & 74.9 & 18.1 & 6.9 \\
\hline & 2479.0 & 68.0 & 65.8 & 2.2 & 10.8 & 7.4 & 3.8 & 0.1 & 5.6 & 4.3 & 76.3 & 12.5 & 11.1 & 78.9 & 12.5 & 8.6 \\
\hline & 2481.0 & 62.4 & 59.6 & 2.8 & 12.4 & 5.4 & 2.6 & 0.2 & 4.6 & 12.4 & 74.3 & 15.5 & 10.2 & 77.8 & 15.5 & 6.7 \\
\hline & 2482.0 & 65.2 & 62.2 & 3.0 & 10.0 & 6.4 & 3.0 & 0.1 & 5.0 & 10.3 & 76.2 & 12.3 & 11.5 & 79.9 & 12.3 & 7.8 \\
\hline & 2483.0 & 65.8 & 63.8 & 2.0 & 14.2 & 5.2 & 5.0 & 1.0 & 5.6 & 3.2 & 74.9 & 16.7 & 8.5 & 77.2 & 16.7 & 6.1 \\
\hline
\end{tabular}


Table 4. Cont

\begin{tabular}{|c|c|c|c|c|c|c|c|c|c|c|c|c|c|c|c|c|}
\hline \multirow{2}{*}{ Borehole } & \multirow{2}{*}{$\begin{array}{c}\text { Depth } \\
\text { (m) }\end{array}$} & $Q t$ & Qm & $Q p$ & $\mathbf{F}$ & $\mathbf{L}$ & GL & Acc & $\mathrm{Cmt}$ & $M x$ & & mFLt & & & tFL ( & \\
\hline & & $(\%)$ & $(\%)$ & $(\%)$ & $(\%)$ & $(\%)$ & $(\%)$ & $(\%)$ & $(\%)$ & $(\%)$ & Qm & F & Lt & $\mathrm{Qt}$ & F & L \\
\hline & 2701.3 & 66.2 & 64.2 & 2.0 & 13.8 & 6.6 & 4.2 & 0.3 & 4.2 & 4.7 & 74.1 & 15.9 & 9.9 & 76.4 & 15.9 & 7.6 \\
\hline & 2702.5 & 68.4 & 66.6 & 1.8 & 14.2 & 5.6 & 1.0 & 0.1 & 6.4 & 4.3 & 75.5 & 16.1 & 8.4 & 77.6 & 16.1 & 6.3 \\
\hline & 2703.0 & 61.0 & 59.0 & 2.0 & 14.0 & 5.0 & 4.0 & 0.8 & 6.4 & 8.8 & 73.8 & 17.5 & 8.8 & 76.3 & 17.5 & 6.3 \\
\hline & 2704.0 & 52.2 & 51.8 & 0.4 & 15.2 & 6.2 & 4.0 & 0.4 & 8.6 & 13.4 & 70.4 & 20.7 & 9.0 & 70.9 & 20.7 & 8.4 \\
\hline & 2705.0 & 59.8 & 59.6 & 0.2 & 18.8 & 6.2 & 3.0 & 0.4 & 4.2 & 7.6 & 70.3 & 22.2 & 7.5 & 70.5 & 22.2 & 7.3 \\
\hline & 2721.0 & 60.4 & 60.2 & 0.2 & 19.8 & 5.8 & 3.0 & 0.2 & 3.0 & 7.8 & 70.0 & 23.0 & 7.0 & 70.2 & 23.0 & 6.7 \\
\hline & 2722.0 & 66.0 & 65.4 & 0.6 & 15.2 & 7.8 & 2.2 & 0.2 & 1.8 & 6.8 & 73.5 & 17.1 & 9.4 & 74.2 & 17.1 & 8.8 \\
\hline & 2724.0 & 60.2 & 59.8 & 0.4 & 10.6 & 5.6 & 3.6 & 0.8 & 9.4 & 9.8 & 78.3 & 13.9 & 7.9 & 78.8 & 13.9 & 7.3 \\
\hline & 2726.0 & 60.6 & 59.2 & 1.4 & 13.6 & 7.2 & 2.4 & 0.5 & 5.8 & 9.9 & 72.7 & 16.7 & 10.6 & 74.4 & 16.7 & 8.8 \\
\hline & 2728.0 & 62.0 & 61.0 & 1.0 & 17.6 & 5.8 & 3.2 & 0.6 & 3.8 & 7.0 & 71.4 & 20.6 & 8.0 & 72.6 & 20.6 & 6.8 \\
\hline & 2730.0 & 61.0 & 60.4 & 0.6 & 15.2 & 9.6 & 1.4 & 0.1 & 5.8 & 6.9 & 70.4 & 17.7 & 11.9 & 71.1 & 17.7 & 11.2 \\
\hline & 2970.0 & 60.0 & 59.0 & 1.0 & 15.0 & 8.4 & 3.0 & 0.4 & 4.6 & 8.6 & 70.7 & 18.0 & 11.3 & 71.9 & 18.0 & 10.1 \\
\hline & 2973.0 & 61.4 & 60.0 & 1.4 & 13.8 & 9.4 & 3.0 & 0.2 & 4.2 & 8.0 & 70.9 & 16.3 & 12.8 & 72.6 & 16.3 & 11.1 \\
\hline E-AJ1 & 2975.0 & 60.2 & 58.8 & 1.4 & 10.0 & 8.2 & 5.0 & 0.0 & 10.0 & 6.6 & 75.0 & 12.8 & 12.2 & 76.8 & 12.8 & 10.5 \\
\hline & 2977.0 & 60.0 & 59.8 & 0.2 & 15.0 & 10.0 & 5.0 & 0.0 & 5.0 & 5.0 & 70.4 & 17.6 & 12.0 & 70.6 & 17.6 & 11.8 \\
\hline & 2979.0 & 60.4 & 59.6 & 0.8 & 14.2 & 5.6 & 0.4 & 0.2 & 7.6 & 11.6 & 74.3 & 17.7 & 8.0 & 75.3 & 17.7 & 7.0 \\
\hline & 2982.0 & 60.0 & 59.8 & 0.2 & 15.0 & 10.0 & 3.2 & 0.1 & 5.0 & 6.7 & 70.4 & 17.6 & 12.0 & 70.6 & 17.6 & 11.8 \\
\hline & 3037.0 & 60.2 & 59.6 & 0.6 & 14.4 & 5.2 & 2.2 & 1.0 & 5.0 & 12.0 & 74.7 & 18.0 & 7.3 & 75.4 & 18.0 & 6.5 \\
\hline & 3039.0 & 62.0 & 61.2 & 0.8 & 12.0 & 5.2 & 3.8 & 0.4 & 5.8 & 10.8 & 77.3 & 15.2 & 7.6 & 78.3 & 15.2 & 6.6 \\
\hline & 3041.0 & 65.0 & 64.0 & 1.0 & 10.4 & 9.6 & 3.0 & 0.8 & 4.2 & 7.0 & 75.3 & 12.2 & 12.5 & 76.5 & 12.2 & 11.3 \\
\hline & 3043.0 & 64.4 & 63.8 & 0.6 & 10.0 & 9.6 & 3.2 & 1.0 & 5.2 & 6.6 & 76.0 & 11.9 & 12.1 & 76.7 & 11.9 & 11.4 \\
\hline & 2692.0 & 64.0 & 63.8 & 0.2 & 10.6 & 10.2 & 5.0 & 0.4 & 4.4 & 5.4 & 75.2 & 12.5 & 12.3 & 75.5 & 12.5 & 12.0 \\
\hline & 2695.0 & 65.6 & 64.4 & 1.2 & 14.6 & 9.8 & 2.6 & 0.6 & 3.2 & 3.6 & 71.6 & 16.2 & 12.2 & 72.9 & 16.2 & 10.9 \\
\hline & 2698.0 & 64.6 & 63.8 & 0.8 & 16.6 & 5.4 & 5.6 & 0.6 & 3.8 & 3.4 & 73.7 & 19.2 & 7.2 & 74.6 & 19.2 & 6.2 \\
\hline & 2701.0 & 64.0 & 63.6 & 0.4 & 14.0 & 9.0 & 5.0 & 0.0 & 3.0 & 5.0 & 73.1 & 16.1 & 10.8 & 73.6 & 16.1 & 10.3 \\
\hline & 2705.0 & 64.2 & 63.2 & 1.0 & 14.4 & 10.2 & 2.8 & 0.6 & 2.8 & 5.0 & 71.2 & 16.2 & 12.6 & 72.3 & 16.2 & 11.5 \\
\hline & 2708.0 & 61.2 & 60.0 & 1.2 & 14.8 & 9.2 & 5.0 & 1.0 & 3.8 & 5.0 & 70.4 & 17.4 & 12.2 & 71.8 & 17.4 & 10.8 \\
\hline & 2828.0 & 60.0 & 59.4 & 0.6 & 13.8 & 8.6 & 3.6 & 0.0 & 3.6 & 10.4 & 72.1 & 16.7 & 11.2 & 72.8 & 16.7 & 10.4 \\
\hline & 2829.0 & 60.4 & 59.8 & 0.6 & 14.0 & 8.8 & 2.8 & 0.6 & 3.8 & 9.6 & 71.9 & 16.8 & 11.3 & 72.6 & 16.8 & 10.6 \\
\hline & 2830.0 & 62.0 & 61.8 & 0.2 & 14.4 & 8.6 & 3.6 & 0.4 & 3.6 & 7.4 & 72.7 & 16.9 & 10.4 & 72.9 & 16.9 & 10.1 \\
\hline & 2832.0 & 68.4 & 67.6 & 0.8 & 13.8 & 8.0 & 2.0 & 0.2 & 2.4 & 5.2 & 74.9 & 15.3 & 9.8 & 75.8 & 15.3 & 8.9 \\
\hline & 2834.0 & 64.6 & 64.4 & 0.2 & 13.4 & 6.4 & 2.8 & 0.2 & 3.8 & 8.8 & 76.3 & 15.9 & 7.8 & 76.5 & 15.9 & 7.6 \\
\hline E-BA1 & 2836.0 & 63.2 & 62.8 & 0.4 & 14.6 & 7.2 & 3.6 & 0.6 & 3.6 & 7.2 & 73.9 & 17.2 & 8.9 & 74.4 & 17.2 & 8.5 \\
\hline & 2838.0 & 64.6 & 64.0 & 0.6 & 14.0 & 5.8 & 2.4 & 0.4 & 5.0 & 7.8 & 75.8 & 16.6 & 7.6 & 76.5 & 16.6 & 6.9 \\
\hline & 2839.0 & 59.8 & 58.4 & 1.4 & 14.2 & 7.6 & 2.0 & 0.6 & 4.4 & 11.4 & 71.6 & 17.4 & 11.0 & 73.3 & 17.4 & 9.3 \\
\hline & 2842.0 & 59.6 & 59.4 & 0.2 & 13.8 & 7.0 & 3.4 & 0.2 & 6.0 & 10.0 & 73.9 & 17.2 & 9.0 & 74.1 & 17.2 & 8.7 \\
\hline & 2843.0 & 55.6 & 54.6 & 1.0 & 14.4 & 7.4 & 3.0 & 0.4 & 7.0 & 12.2 & 70.5 & 18.6 & 10.9 & 71.8 & 18.6 & 9.6 \\
\hline & 2850.0 & 64.2 & 63.8 & 0.4 & 18.6 & 6.0 & 2.2 & 0.0 & 2.2 & 6.8 & 71.8 & 20.9 & 7.2 & 72.3 & 20.9 & 6.8 \\
\hline & 2537.2 & 60.4 & 60.0 & 0.4 & 13.0 & 6.2 & 2.6 & 0.0 & 4.0 & 13.8 & 75.4 & 16.3 & 8.3 & 75.9 & 16.3 & 7.8 \\
\hline & 2537.7 & 62.0 & 61.8 & 0.2 & 14.0 & 6.0 & 2.0 & 0.2 & 6.2 & 9.6 & 75.4 & 17.1 & 7.6 & 75.6 & 17.1 & 7.3 \\
\hline & 2539.0 & 55.6 & 54.2 & 1.4 & 14.0 & 6.2 & 4.2 & 0.2 & 6.8 & 13.0 & 71.5 & 18.5 & 10.0 & 73.4 & 18.5 & 8.2 \\
\hline & 2541.0 & 68.2 & 67.2 & 1.0 & 16.4 & 5.8 & 1.8 & 0.4 & 2.2 & 5.2 & 74.3 & 18.1 & 7.5 & 75.4 & 18.1 & 6.4 \\
\hline & 2543.0 & 66.0 & 65.8 & 0.2 & 13.2 & 6.2 & 2.2 & 0.6 & 2.6 & 9.2 & 77.0 & 15.5 & 7.5 & 77.3 & 15.5 & 7.3 \\
\hline & 2546.0 & 65.0 & 64.4 & 0.6 & 15.8 & 6.8 & 2.0 & 0.0 & 2.4 & 8.0 & 73.5 & 18.0 & 8.4 & 74.2 & 18.0 & 7.8 \\
\hline & 2548.0 & 62.2 & 60.4 & 1.8 & 15.2 & 6.8 & 4.2 & 0.4 & 3.6 & 7.6 & 71.7 & 18.1 & 10.2 & 73.9 & 18.1 & 8.1 \\
\hline & 2551.0 & 60.0 & 59.8 & 0.2 & 13.8 & 6.4 & 4.0 & 0.4 & 3.6 & 11.8 & 74.6 & 17.2 & 8.2 & 74.8 & 17.2 & 8.0 \\
\hline & 2553.0 & 57.8 & 57.4 & 0.4 & 13.6 & 6.0 & 3.6 & 0.3 & 7.0 & 11.7 & 74.2 & 17.6 & 8.3 & 74.7 & 17.6 & 7.8 \\
\hline & 2556.0 & 61.6 & 60.8 & 0.8 & 13.0 & 5.0 & 2.2 & 0.6 & 5.2 & 12.4 & 76.4 & 16.3 & 7.3 & 77.4 & 16.3 & 6.3 \\
\hline & 2659.0 & 62.0 & 60.6 & 1.4 & 15.6 & 6.0 & 2.4 & 0.8 & 3.6 & 9.6 & 72.5 & 18.7 & 8.9 & 74.2 & 18.7 & 7.2 \\
\hline & 2660.0 & 60.2 & 59.6 & 0.6 & 14.4 & 7.2 & 3.2 & 0.6 & 4.2 & 10.2 & 72.9 & 17.6 & 9.5 & 73.6 & 17.6 & 8.8 \\
\hline & 2662.0 & 61.2 & 60.0 & 1.2 & 14.0 & 8.2 & 2.6 & 0.4 & 3.6 & 10.0 & 71.9 & 16.8 & 11.3 & 73.4 & 16.8 & 9.8 \\
\hline & 2663.0 & 61.6 & 60.8 & 0.8 & 16.4 & 7.8 & 2.4 & 0.6 & 3.2 & 8.0 & 70.9 & 19.1 & 10.0 & 71.8 & 19.1 & 9.1 \\
\hline & 2665.0 & 63.2 & 62.2 & 1.0 & 13.6 & 7.4 & 3.6 & 0.0 & 3.8 & 8.4 & 73.9 & 16.2 & 10.0 & 75.1 & 16.2 & 8.8 \\
\hline & 2719.0 & 64.0 & 63.8 & 0.2 & 14.0 & 5.2 & 3.2 & 0.2 & 4.2 & 9.2 & 76.7 & 16.8 & 6.5 & 76.9 & 16.8 & 6.3 \\
\hline & 2721.0 & 60.2 & 60.0 & 0.2 & 15.0 & 6.6 & 3.0 & 0.6 & 4.6 & 10.0 & 73.3 & 18.3 & 8.3 & 73.6 & 18.3 & 8.1 \\
\hline & 2723.0 & 57.6 & 56.6 & 1.0 & 14.8 & 6.8 & 4.2 & 0.0 & 5.6 & 11.0 & 71.5 & 18.7 & 9.8 & 72.7 & 18.7 & 8.6 \\
\hline E-BB1 & 2847.0 & 59.0 & 58.8 & 0.2 & 16.8 & 6.0 & 2.0 & 0.4 & 5.0 & 10.8 & 71.9 & 20.5 & 7.6 & 72.1 & 20.5 & 7.3 \\
\hline & 2849.0 & 61.4 & 60.4 & 1.0 & 13.8 & 7.6 & 2.4 & 0.2 & 5.0 & 9.6 & 72.9 & 16.7 & 10.4 & 74.2 & 16.7 & 9.2 \\
\hline & 2851.0 & 61.8 & 61.4 & 0.4 & 14.2 & 6.0 & 1.8 & 0.6 & 4.8 & 10.8 & 74.9 & 17.3 & 7.8 & 75.4 & 17.3 & 7.3 \\
\hline & 2853.0 & 60.0 & 59.0 & 1.0 & 11.0 & 5.2 & 3.0 & 0.8 & 8.0 & 12.0 & 77.4 & 14.4 & 8.1 & 78.7 & 14.4 & 6.8 \\
\hline & 2855.0 & 61.0 & 60.6 & 0.4 & 14.0 & 5.8 & 1.4 & 0.2 & 5.8 & 11.8 & 75.0 & 17.3 & 7.7 & 75.5 & 17.3 & 7.2 \\
\hline & 2858.0 & 58.0 & 57.2 & 0.8 & 12.6 & 6.6 & 3.0 & 0.6 & 7.0 & 12.2 & 74.1 & 16.3 & 9.6 & 75.1 & 16.3 & 8.5 \\
\hline & 2860.0 & 60.2 & 59.4 & 0.8 & 13.6 & 7.0 & 2.0 & 0.2 & 5.0 & 12.0 & 73.5 & 16.8 & 9.7 & 74.5 & 16.8 & 8.7 \\
\hline & 2863.0 & 55.4 & 55.2 & 0.2 & 16.0 & 6.8 & 2.4 & 0.0 & 6.8 & 12.6 & 70.6 & 20.5 & 9.0 & 70.8 & 20.5 & 8.7 \\
\hline & 2865.0 & 57.0 & 56.6 & 0.4 & 13.0 & 6.0 & 2.4 & 0.4 & 8.4 & 12.8 & 74.5 & 17.1 & 8.4 & 75.0 & 17.1 & 7.9 \\
\hline & 2872.0 & 57.2 & 57.0 & 0.2 & 15.2 & 7.0 & 2.2 & 0.1 & 6.0 & 12.3 & 71.8 & 19.1 & 9.1 & 72.0 & 19.1 & 8.8 \\
\hline & 2872.8 & 59.2 & 59.0 & 0.2 & 14.0 & 5.4 & 4.2 & 0.2 & 5.0 & 13.0 & 75.1 & 17.8 & 7.1 & 75.3 & 17.8 & 6.9 \\
\hline & 2873.0 & 57.6 & 56.2 & 1.4 & 13.6 & 5.6 & 3.0 & 0.1 & 7.2 & 12.9 & 73.2 & 17.7 & 9.1 & 75.0 & 17.7 & 7.3 \\
\hline & 2873.8 & 56.0 & 55.6 & 0.4 & 15.6 & 7.8 & 4.0 & 0.4 & 6.6 & 9.6 & 70.0 & 19.6 & 10.3 & 70.5 & 19.6 & 9.8 \\
\hline & 3280.4 & 59.8 & 59.6 & 0.2 & 17.6 & 8.0 & 1.8 & 0.6 & 4.2 & 8.0 & 69.8 & 20.6 & 9.6 & 70.0 & 20.6 & 9.4 \\
\hline & 3282.0 & 59.2 & 59.0 & 0.2 & 18.0 & 8.2 & 3.0 & 0.0 & 2.0 & 9.6 & 69.1 & 21.1 & 9.8 & 69.3 & 21.1 & 9.6 \\
\hline & 3284.0 & 57.6 & 57.4 & 0.2 & 12.4 & 7.2 & 2.0 & 0.2 & 9.0 & 11.6 & 74.4 & 16.1 & 9.6 & 74.6 & 16.1 & 9.3 \\
\hline & 3286.0 & 60.0 & 59.8 & 0.2 & 13.6 & 9.0 & 1.8 & 0.2 & 6.0 & 9.4 & 72.4 & 16.5 & 11.1 & 72.6 & 16.5 & 10.9 \\
\hline & 3288.0 & 59.0 & 58.4 & 0.6 & 14.0 & 6.0 & 3.8 & 0.0 & 6.2 & 11.0 & 73.9 & 17.7 & 8.4 & 74.7 & 17.7 & 7.6 \\
\hline & 3292.7 & 59.8 & 59.4 & 0.4 & 16.2 & 7.2 & 2.6 & 0.0 & 5.6 & 8.6 & 71.4 & 19.5 & 9.1 & 71.9 & 19.5 & 8.7 \\
\hline & 3294.0 & 58.0 & 57.0 & 1.0 & 13.6 & 7.8 & 1.6 & 0.0 & 7.0 & 12.0 & 71.8 & 17.1 & 11.1 & 73.0 & 17.1 & 9.8 \\
\hline
\end{tabular}


Table 4. Cont.

\begin{tabular}{|c|c|c|c|c|c|c|c|c|c|c|c|c|c|c|c|c|}
\hline \multirow{2}{*}{ Borehole } & \multirow{2}{*}{$\begin{array}{c}\text { Depth } \\
\text { (m) }\end{array}$} & \multirow{2}{*}{$\begin{array}{l}\mathrm{Qt} \\
(\%)\end{array}$} & \multirow{2}{*}{$\begin{array}{l}\text { Qm } \\
(\%)\end{array}$} & \multirow{2}{*}{$\begin{array}{l}\text { Qp } \\
(\%)\end{array}$} & \multirow{2}{*}{$\begin{array}{c}F \\
(\%)\end{array}$} & \multirow{2}{*}{$\begin{array}{c}\mathrm{L} \\
(\%)\end{array}$} & \multirow{2}{*}{$\begin{array}{l}\text { GL } \\
(\%)\end{array}$} & \multirow{2}{*}{$\begin{array}{l}\text { Acc } \\
(\%)\end{array}$} & \multirow{2}{*}{$\begin{array}{c}\text { Cmt } \\
(\%)\end{array}$} & \multirow{2}{*}{$\begin{array}{l}\text { Mx } \\
(\%)\end{array}$} & \multicolumn{3}{|c|}{ QmFLt (\%) } & \multicolumn{3}{|c|}{ QtFL (\%) } \\
\hline & & & & & & & & & & & Qm & F & Lt & $\mathrm{Qt}$ & F & $\mathbf{L}$ \\
\hline \multirow{8}{*}{ E-D3 } & 3261.2 & 62.4 & 62.2 & 0.2 & 13.4 & 7.2 & 1.6 & 0.2 & 4.4 & 10.8 & 74.9 & 16.1 & 8.9 & 75.2 & 16.1 & 8.7 \\
\hline & 3262.9 & 61.8 & 60.4 & 1.4 & 16.8 & 5.8 & 2.8 & 0.6 & 3.8 & 8.4 & 71.6 & 19.9 & 8.5 & 73.2 & 19.9 & 6.9 \\
\hline & 3266.5 & 60.0 & 58.6 & 1.4 & 12.4 & 6.0 & 3.8 & 0.2 & 7.8 & 9.8 & 74.7 & 15.8 & 9.4 & 76.5 & 15.8 & 7.7 \\
\hline & 3268.0 & 63.0 & 62.2 & 0.8 & 15.0 & 6.4 & 2.4 & 0.8 & 4.4 & 8.0 & 73.7 & 17.8 & 8.5 & 74.6 & 17.8 & 7.6 \\
\hline & 3269.0 & 58.4 & 58.0 & 0.4 & 14.4 & 6.8 & 3.6 & 0.0 & 5.0 & 11.8 & 72.9 & 18.1 & 9.0 & 73.4 & 18.1 & 8.5 \\
\hline & 3526.0 & 62.0 & 60.8 & 1.2 & 14.0 & 6.2 & 3.2 & 0.2 & 5.4 & 9.0 & 74.0 & 17.0 & 9.0 & 75.4 & 17.0 & 7.5 \\
\hline & 3528.5 & 59.2 & 58.2 & 1.0 & 13.4 & 5.2 & 2.2 & 0.0 & 6.2 & 13.8 & 74.8 & 17.2 & 8.0 & 76.1 & 17.2 & 6.7 \\
\hline & 3529.5 & 62.8 & 62.2 & 0.6 & 15.6 & 6.2 & 2.6 & 0.1 & 4.2 & 8.5 & 73.5 & 18.4 & 8.0 & 74.2 & 18.4 & 7.3 \\
\hline
\end{tabular}

Note: $\mathrm{Qt}=$ total quartz $(\mathrm{Qm}+\mathrm{Qp}), \mathrm{Qm}=$ monocrystalline quartz, $\mathrm{Qp}=$ Polycrystalline quartz, $\mathrm{F}=\mathrm{Feldspar}$, $\mathrm{L}=$ Unstable siliciclastic lithic fragments $(\mathrm{Lv}+\mathrm{Ls}+\mathrm{Lm}), \mathrm{Ls}=$ Sedimentary lithic fragment, Lv = Volcanic plus igneous lithic fragment, $\mathrm{Lm}=$ Metamorphic lithic fragment, Lt = Total siliciclastic lithic fragment $(\mathrm{L}+\mathrm{Qp})$, $\mathrm{GL}=$ Detrital glauconite, $\mathrm{Acc}=$ Accessory minerals, $\mathrm{cmt}=$ Cement, $\mathrm{Mx}=$ Matrix.

\subsection{Sandstone Classification}

The most widely used and effective methods for classifying sandstones combines the textural Criteria (i.e., proportion of the matrix) with the compositional criteria (i.e., percentages of the framework grains) $[7,12,35,41-43]$. In this study, the classification of the Bredasdorp sandstones is based on the classification schemes proposed by $[7,35,41-43]$. These schemes are based on the percentages of the framework grains (total quartz, feldspar, and lithic fragments) in a triangular plot such that these three components serve as the end members to form a Qt-F-L ternary diagram. The Folk's classification scheme revealed important information about provenance, with the rock's name showing details of its composition, as established and reported by [44,45]. In addition, the classification method of [46], which depends on the relative proportions of matrix (silt and clay materials), was used to classify the sandstones.

The classification method of [35] revealed that the sandstones can be classified as feldspathic arenite Figure 7, whereas the [41] method shows that the sandstones could be classified as subarkosic arenite Figure 8. The [35] scheme revealed that the sandstones are subarkosic arenite and arkosic litharenite (lithic arkose; Figure 9). The method of [7] indicated that the sandstones can be classified as subfeldspathic and lithofeldspathic sandstones Figure 10. According to [47], if the amount of matrix present in a sandstone is less than $15 \%$, the rock could be referred to as an arenite, and if the percentage varies between 15 and $75 \%$, the sandstone is a wacke. Based on the percentages of the matrix presented in Table 3, the sandstones can be classified as arenites. In addition, [47] reported that at least $25 \%$ of feldspar must be present in a sandstone for it to be called a feldspathic arenite or arkosic arenite arkose. Using the same criteria, at least $25 \%$ of lithic fragments in a sandstone makes it a lithic arenite. Likewise, a sandstone with intermediate percentages of feldspar or lithic fragments varying between 5 and $25 \%$ can be called subarkosic arenite and sublithic arenite [47]. Based on the percentages of feldspar and lithic fragments shown in Table 3, the sandstones are subarkosic and sublithic arenites. This classification scheme that is based on the matrix content is supported or in agreement with the background QFL ternary diagram of $[7,35]$, where the sandstones are plotted in the field of subarkosic arenite and lithic arkose Figures 8-10. 


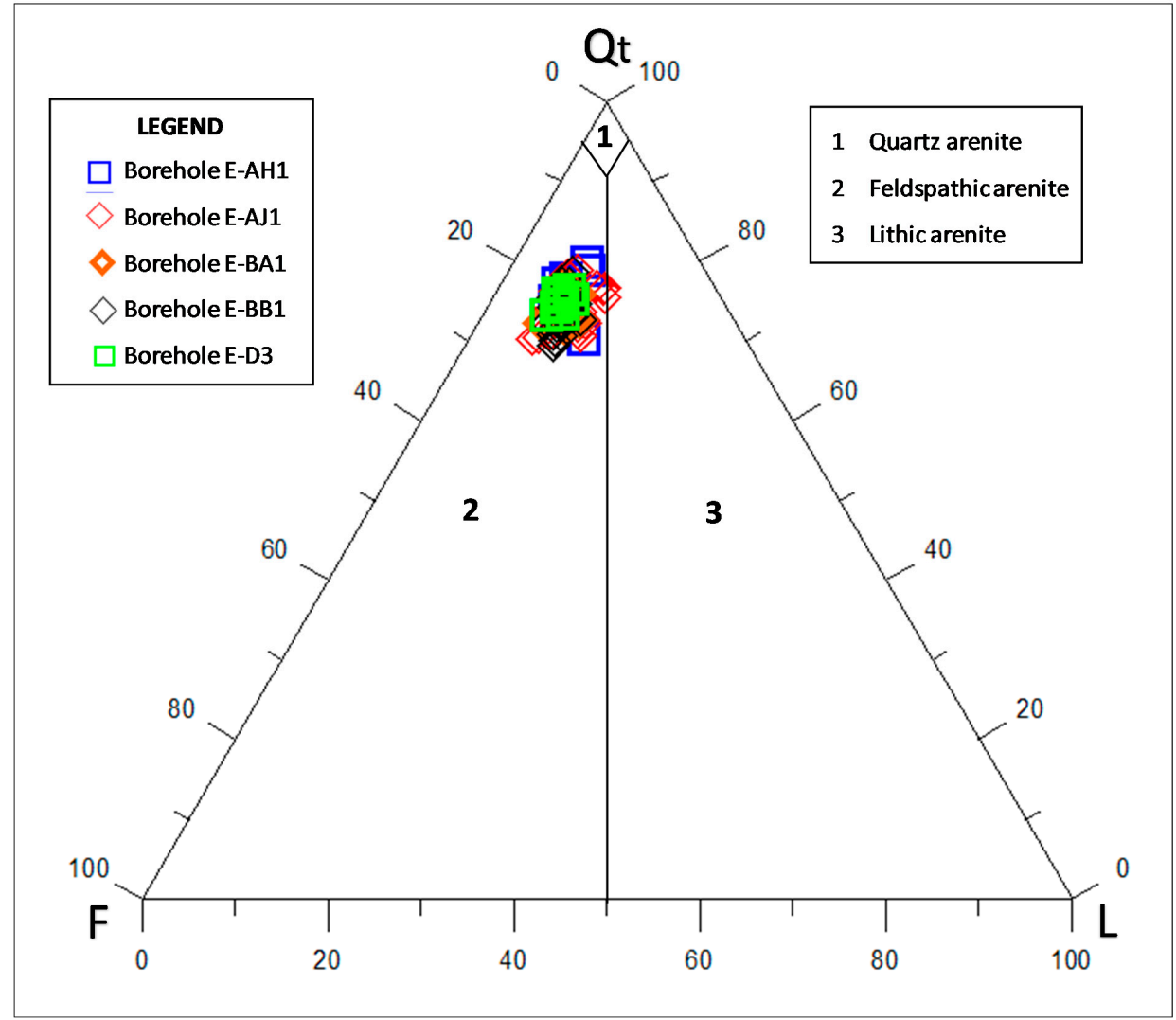

Figure 7. Total quartz-feldspar-lithic fragments (Qt-F-L) modal data plot of the Bredasdorp sandstones on the background ternary diagram of [43].

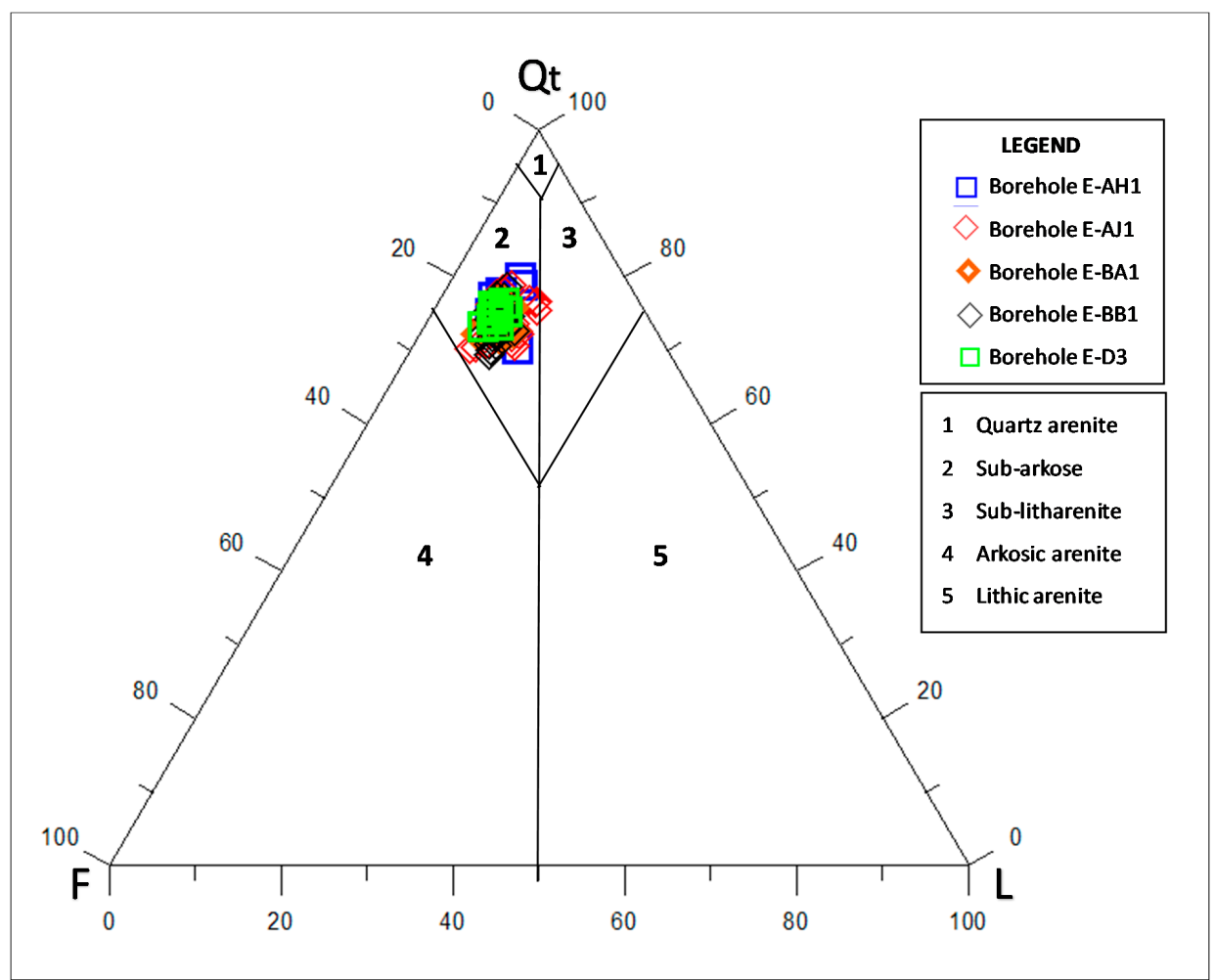

Figure 8. Sandstone modal data plot of the total quartz-feldspar-lithic fragments (Qt-F-L) on the background ternary diagram of [41]. 


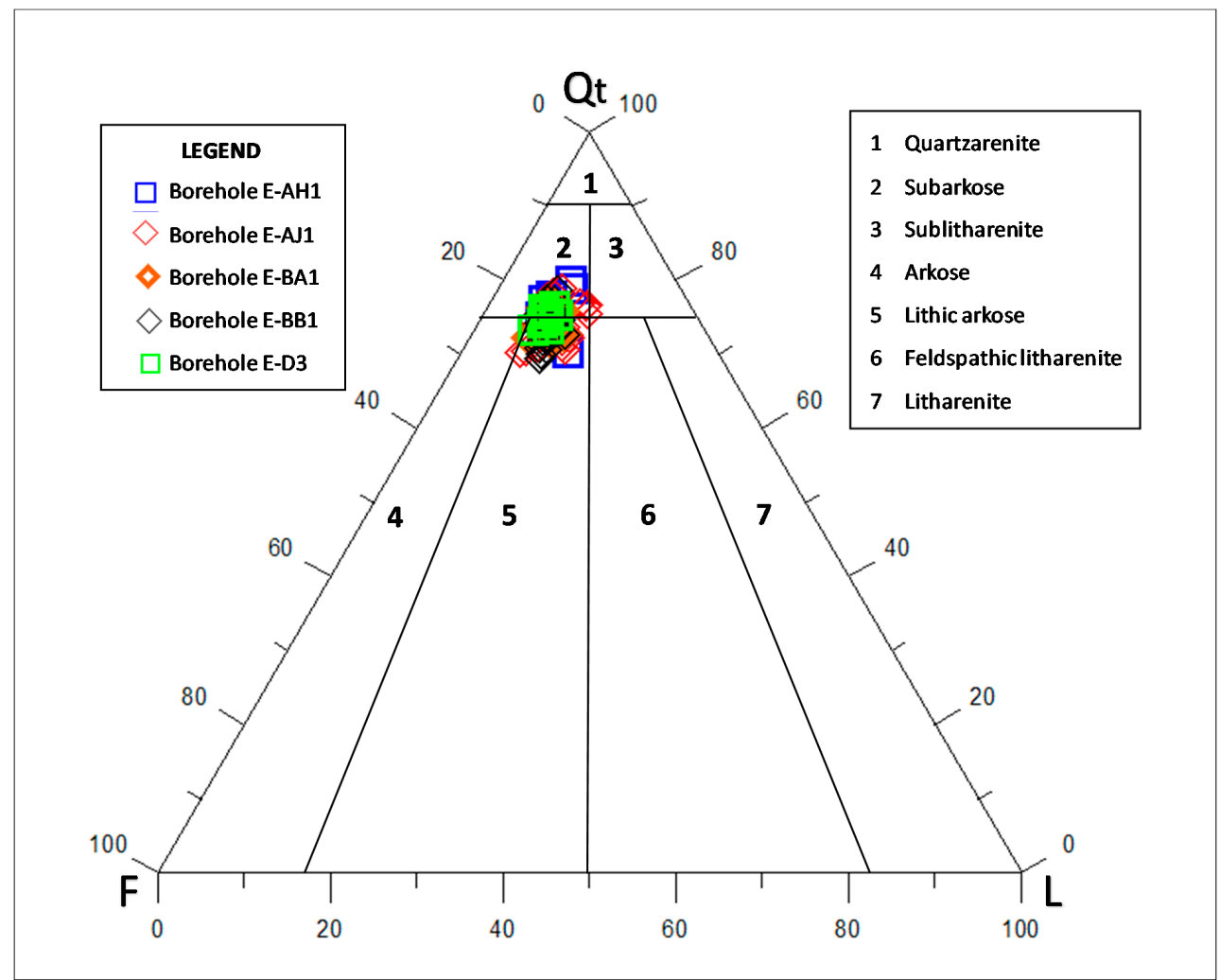

Figure 9. Sandstone modal data plot of the total quartz-feldspar-lithic fragments (Qt-F-L) on the background ternary diagram of [35].

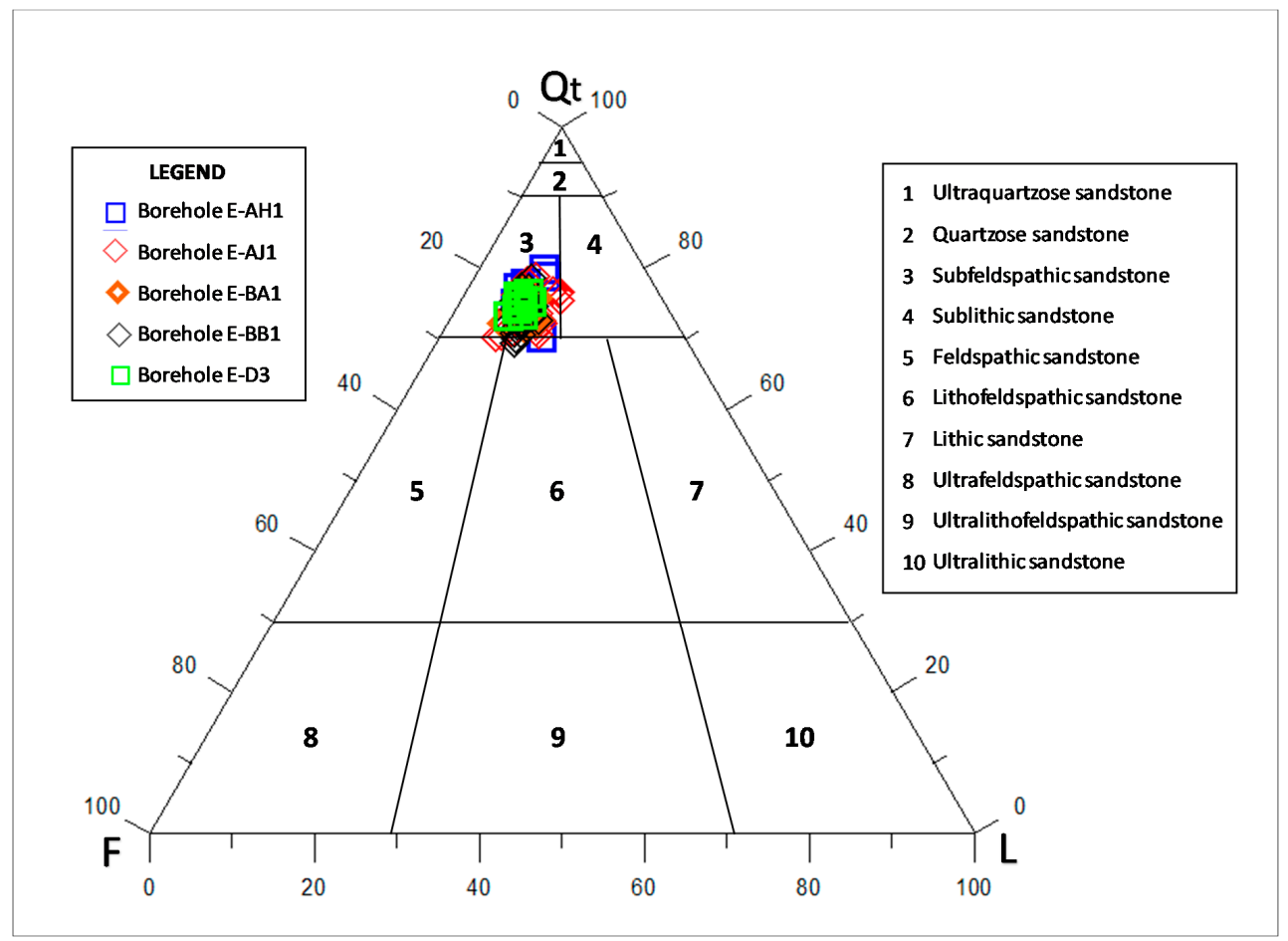

Figure 10. Mineralogical classification of the Bredasdorp sandstones using the modal data plot of the total quartz-feldspar-lithic fragments (Qt-F-L) on the background ternary diagram of [7]. 


\subsection{Provenance and Tectonic Setting}

The provenance studies of sandstones have revealed that different tectonic environments consist of evolutionary patterns in their detritus and display certain compositional varieties during re-deposition [7]. The authors of [48] indicated that each type of provenance usually contribute distinctive detritus specially to the nearby sedimentary basin. Therefore, the siliciclastic (i.e., sandstone) detrital framework preserves comprehensive information on the sediments' mode of transportation and deposition as well as the sandstone provenance, particularly after modification of the original detritus as a result of interaction with physical, chemical, and biological diagenetical processes [6]. Siliciclastic rocks also hold vital information used for interpreting the compositional tectonic setting as well as the evolution of the continental crust, which can be related to the environment of deposition [49,50]. Several researchers, including [3-7,48-53], have related detrital framework grains of sandstone to different provenance settings (i.e., stable cratons, basement uplifts, magmatic arcs, and recycled orogens) using the Qt-F-L ternary diagram. In order to interpret and discriminate between the different kinds of tectonic settings and provenances, the Bredasdorp sandstones were plotted on the background Qt-F-L ternary diagrams of $[3,6,7,52,53]$.

In the Qt-F-L ternary diagram of [3], the Bredasdorp sandstones fall in the recycled orogen field Figure 11, indicating that the sandstones were mainly sourced from siliciclastic rocks with lesser volcanic rocks, to some extent, the rocks have been metamorphosed and open to erosion as a result of orogenic uplifted fold-belts and thrust sheets [7]. As evidenced in the modal composition, Ref. [7] reported that sands that are provenance from recycled orogen usually have low percentages of feldspar due to the fact that igneous rocks are not the main sources. The ternary plot of Qt-F-L on the background provenance diagram of [6] revealed that the samples fall in the transitional continental and craton interior fields of the continental blocks Figure 12, suggesting that the sandstones were derived from stable shields and platforms or uplifted areas, which marks plate boundaries and patterns of intraplate deformation that divide the continental blocks. As indicated by [7], these basement uplifts are usually present along incipient rift belts, transform ruptures, deep-seated thrusts, and zones of wrench tectonism. Sandstones that plot in the craton field are matured sandstones and are possibly sourced from relatively low-lying granitoid and gneissic sources, complemented by recycled sands from associated platform or passive margin basins [7]. The dominance of monocrystalline quartz as well as the low percentage of unstable grains, like feldspar and lithic fragments, also support the fact that the sandstones are matured and have undergone long-distance transport along the rift. In the Qt-F-L ternary diagram of [6], the sandstones are plotted in the fields of continental block and recycled orgency provenances with stable craton sources and uplifting in the basement complexes Figure 13 . About $80 \%$ of the samples are plotted in the continental block provenance, and according to [7], sandstones plotting in the craton field are matured and are possibly derived from relatively low-lying granitoid and gneissic sources, supplemented by recycled sands from an associated platform.

The modal analysis data plot of the sandstones on the Qt-F-L ternary diagrams of [52] revealed that the sandstones are related to the trailing edge setting Figure 14, which is tectonically inactive and where the continental margin is facing a spreading center or rifting resulting in the development of the Bredasdorp Basin on the trailing edge of the continent.

The studied sandstones are believed to be remains of the trailing edges of the huge plates that separated and receded some millions of years ago to form the Bredasdorp Basin. As the edges of the plates slowly contracted and subsided, large amounts of clay-sized materials and sand from the continents were deposited along their seaward side. The samples plotted outside of the tectonic setting fields are possibly due to the effect of intense weathering that the sandstones underwent in the depositional basin. The results of the petrographic and modal compositional analyses revealed that the sandstones have similar characteristics with those of the passive margin setting. As reported by [53], passive margin sandstones derived from plate interiors or stable continental margins usually have a high quartz content, which is also evident in the Bredasdorp sandstones. In a regional context of the evolution of the Bredasdorp Basin, this result presented in this study supports the assumption 
that in the basin, a large composite intracratonic rift basin was generated during Late Jurassic-Early Cretaceous break-up and separation of Gondwana as a result of thermal subsidence in response to a single rifting event.

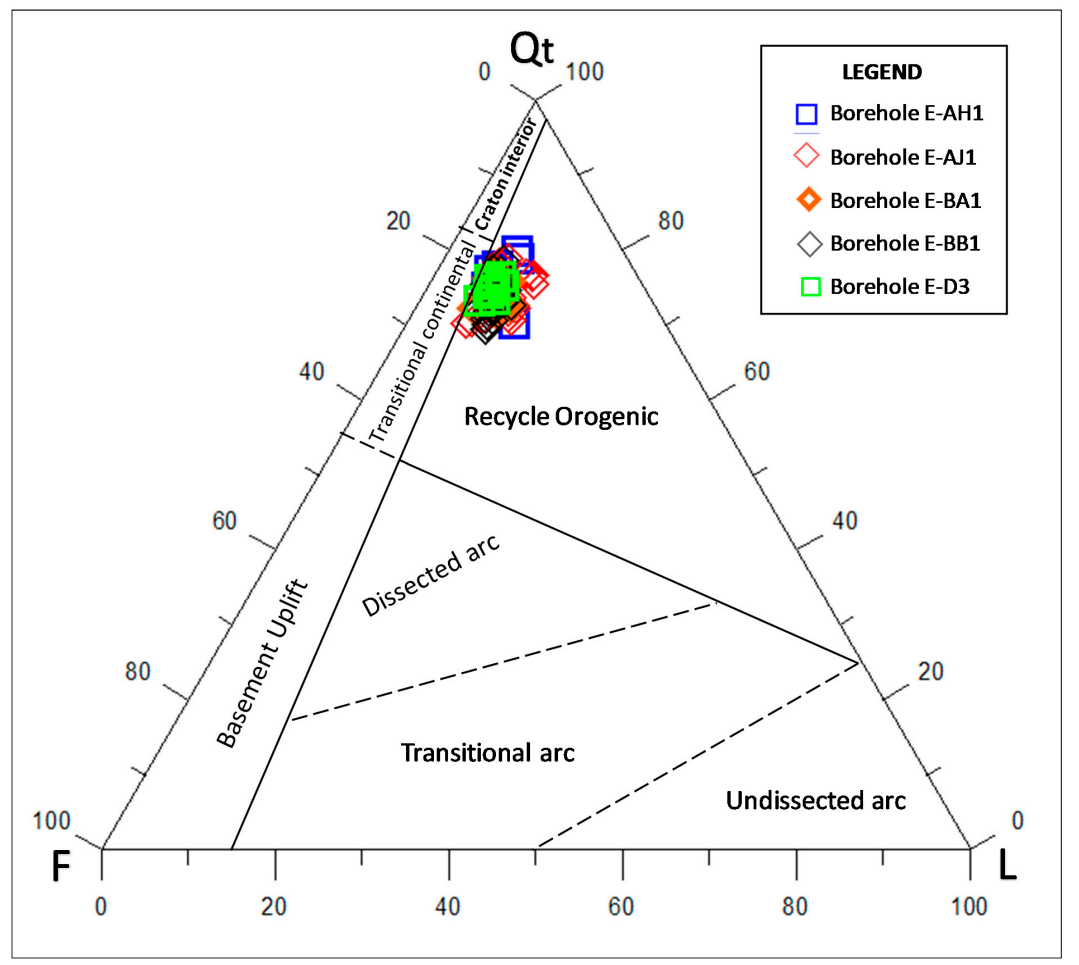

Figure 11. Total quartz-feldspar-lithic fragment (Qt-F-L) plot for framework modes of the Bredasdorp sandstones on the background ternary diagram of [3] showing tectonic provenance.

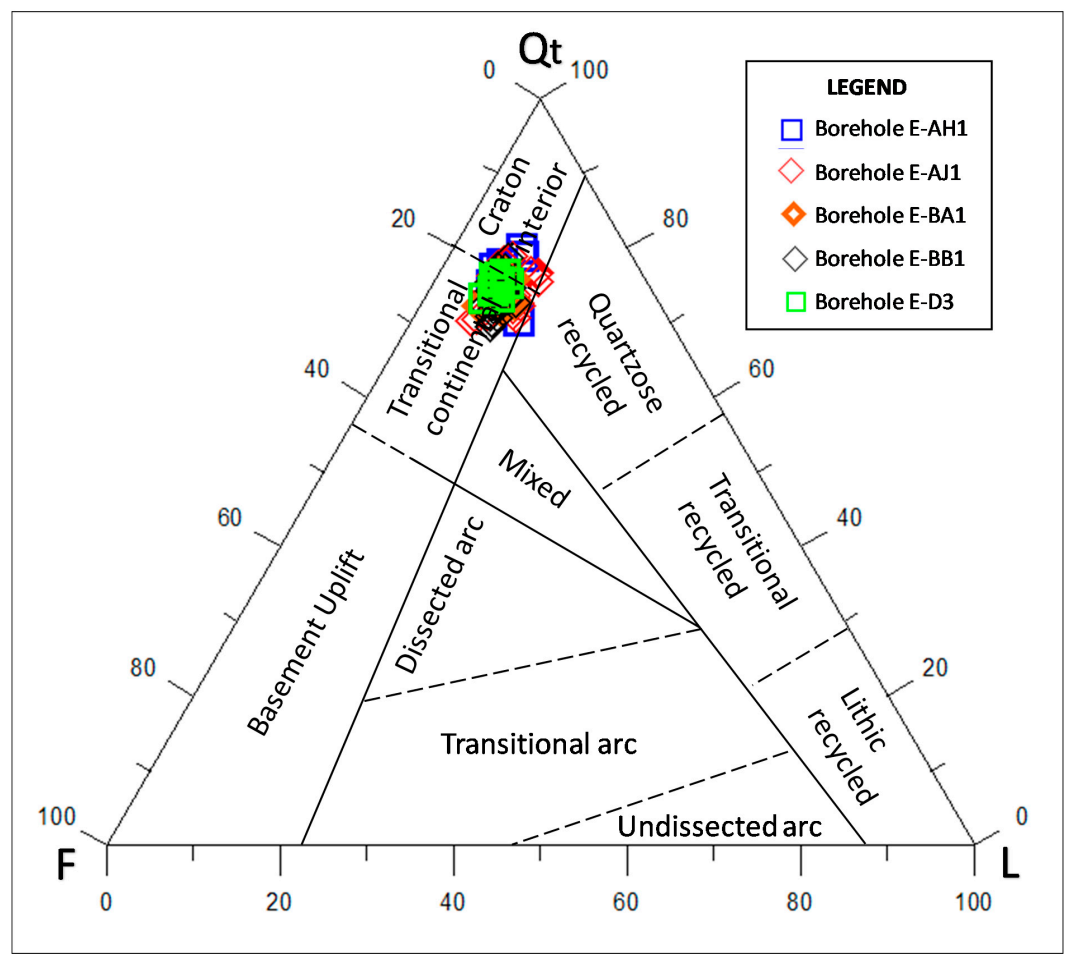

Figure 12. Total quartz-feldspar-lithic fragment (Qt-F-L) plot for framework modes of the Bredasdorp sandstones on the background diagram of [6] showing tectonic provenance. 


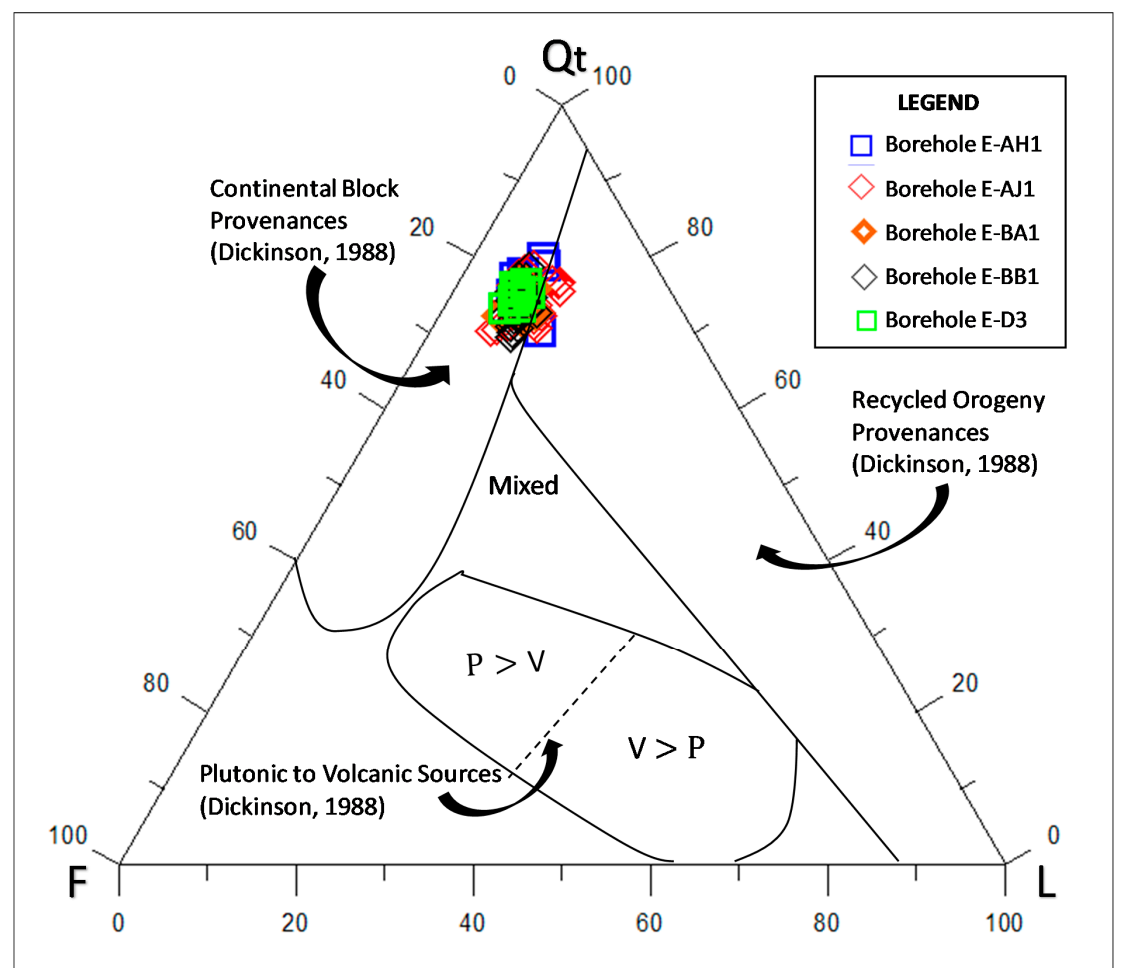

Figure 13. Modal analysis data plot of the Bredasdorp sandstones on the total quartz-feldspar-lithic fragment (Qt-F-L) ternary diagram of [7] showing tectonic provenance.

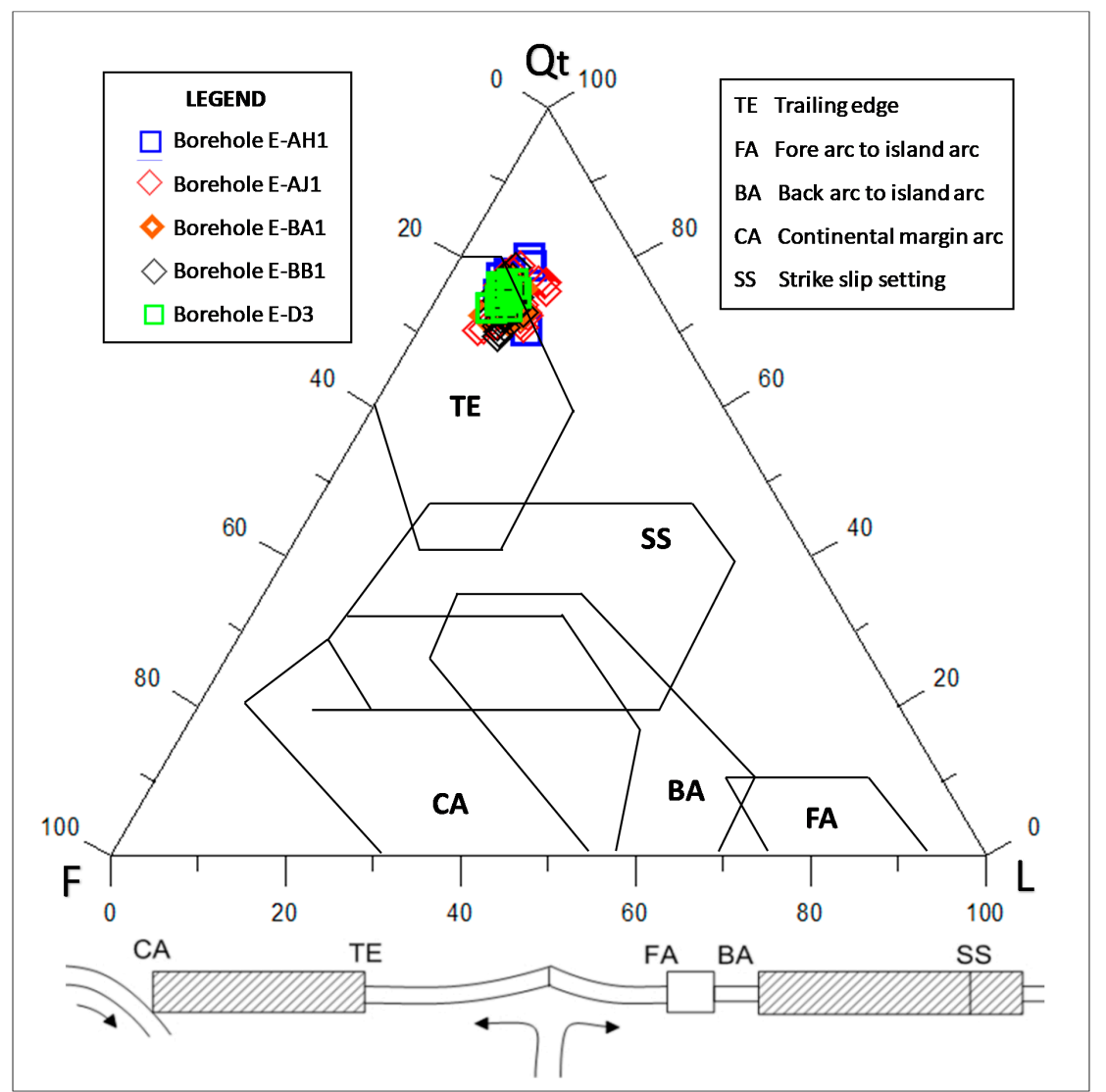

Figure 14. Total quartz-feldspar-lithic fragment (Qt-F-L) scheme proposed by [52] showing tectonic provenance of the Bredasdorp sandstones. 


\section{Conclusions}

The composition, classification, and provenance of the Bredasdorp sandstones were assessed using a combination of petrographical and mineralogical techniques. Petrographic and modal composition studies show that the main detrital components of the sandstones are quartz (mostly monocrystalline quartz), feldspar (mostly K-feldspar), and lithic fragments. The absence of major petrographically distinctive compositional variations in the sandstones perhaps indicates a homogeneity of their source. The Bredasdorp sandstones can be classified as subarkosic arenite with a few lithic arkosic arenite (lithic arkose). The petrographic results suggest the influence of granitic and metamorphic terrains as the main source rock with minor input from subordinate sedimentary rocks. The sandstones are generally fine grained, and the morphology of the grains varies from moderately well sorted to well sorted and subrounded to rounded in shape. These textural attributes indicate long-distance transport of grains from the source region along the rift. The aforementioned characteristics perhaps point to the fact that the Bredasdorp Basin received the mixture of debris derived from a nearby source in the early stage of sedimentation and far away source with sediments' transport along the rift in the later stage of basin development. The provenance analysis indicates that the sandstones are largely derived from granites and granite-gneisses of a continental block tectonic provenance (craton interior and transitional continental), in a rifted continental margin basin setting, suggesting that the sandstones were derived from stable shields and uplifted areas. The aforementioned characteristics indicate that the Bredasdorp sandstones were deposited on a rifted passive continental margin that received enormous amounts of mature detritus from the hinterland areas.

Supplementary Materials: The following are available online at http://www.mdpi.com/2076-3263/10/9/340/s1, Table S1: Textural characteristics of the Bredasdorp sandstones.

Author Contributions: Conceptualization, T.L.B. and K.L.; methodology, T.L.B., K.L. and C.B.; software, O.G. and C.B.; formal analysis, T.L.B., K.L., O.G. and C.B.; data curation, T.L.B., K.L. and C.B.; writing-original draft preparation, T.L.B.; writing-review and editing, K.L. and C.B.; visualization, K.L. and O.G.; All authors have read and agreed to the published version of the manuscript.

Funding: Funding: National Research Foundation- Southern African Systems Analysis Centre (NRF-SASAC; UID: 118768) and the DSI-NRF Centre of Excellence (CoE) for Integrated Mineral and Energy Resource Analysis (CIMERA).

Acknowledgments: The authors are grateful to the National Research Foundation- Southern African Systems Analysis Centre (NRF-SASAC) and the DSI-NRF Centre of Excellence (CoE) for Integrated Mineral and Energy Resource Analysis (CIMERA) for financial support. The Petroleum Agency of South Africa (PASA) and the Govan Mbeki Research and Development Centre (GMRDC) of the University of Fort Hare are appreciated for granting access to the cores and logistic supports, respectively.

Conflicts of Interest: The authors declare no conflict of interest.

\section{References}

1. Petroleum Agency of South Africa, PASA. Petroleum Exploration Information and Opportunities: Petroleum Agency, South Africa Brochure. Available online: https://www.petroleumagencysa.com/images/pdfs/Pet_ expl_opp_broch_2017bw1.pdf (accessed on 17 November 2019).

2. Crook, K.A.W. Lithogenesis and geotectonics: The significance of compositional variation in flysch arenites (greywackes). Modern Anc. Geosyncl. Sediment. 1974, 304-310. [CrossRef]

3. Dickinson, C.A.S.W.R. Plate Tectonics and Sandstone Compositions. AAPG Bull. 1979, 63, $2164-2194$. [CrossRef]

4. Weltje, G.J.; Von Eynatten, H. Quantitative provenance analysis of sediments: Review and outlook. Sediment. Geol. 2004, 171, 1-11. [CrossRef]

5. Dickinson, W.R. Interpreting Provenance Relations from Detrital Modes of Sandstones. In Provenance of Arenites; Springer Science and Business Media LLC: Berlin/Heidelberg, Germany, 1985; pp. 333-361.

6. Dickinson, W.R. Provenance and Sediment Dispersal in Relation to Paleotectonics and Paleogeography of Sedimentary Basins. In New Prespectives in Basin Analysis; Kleinspehn, K.L., Poala, C., Eds.; Springer: New York, NY, USA, 1988; pp. 2-25. 
7. Dickinson, W.R.; Beard, L.S.; Brakenridge, G.R.; Erjavec, J.L.; Ferguson, R.C.; Inman, K.F.; Knepp, R.A.; Lindberg, F.A.; Ryberg, P.T. Provenance of North American Phanerozoic sandstones in relation to tectonic setting. GSA Bull. 1983, 94, 222-235. [CrossRef]

8. Bhatia, M.R. Plate Tectonics and Geochemical Composition of Sandstones. J. Geol. 1983, 91, 611-627. [CrossRef]

9. Cox, R.; Lowe, D.R. A conceptual review of regional-scale controls on the composition of clastic sediment and the co-evolution of continental blocks and their sedimentary cover. J. Sediment. Res. Sect. A Sediment. Pet. Process. Int. J. SEPM 1995, 65, 1-12.

10. Nesbitt, H.W.; Fedo, C.M.; Young, G.M. Quartz and Feldspar Stability, Steady and Non-Steady-State Weathering, and Petrogenesis of Siliciclastic Sands and Muds. J. Geol. 1997, 105, 173-192. [CrossRef]

11. Basu, A.S.; Suttner, L.J.; James, W.C.; Mack, G.H. Re-evaluation of the use of undulatory extinction and crystallinity in detrital quartz for provenance interpretation. J. Sediment. Petrol. 1975, 45, 873-882.

12. Johnson, M.R. Sandstone petrography, provenance, and plate tectonic setting in Gondwana context of the southeastern Cape Karoo Basin. S. Afr. J. Geol. 1991, 94, 137-154.

13. Bordy, E.M.; Hancox, J.P.; Rubidge, B.S. Provenance studies of the late Triassicearly Jurassic Elliot formation, main Karoo Basin, South Africa. S. Afr. J. Geol. 2004, 107, 587-602. [CrossRef]

14. Jafarzadeh, M.; Hosseini-Barzi, M. Petrography and geochemistry of Ahawz sandstone Member of Asmari Formation, Zagros, Iran: Implications on provenance and tectonic setting. Mex. Cienc. Geol. 2008, 25, 247-260.

15. Burden, P.L.A. Soekor, partners explore possibilities in Bredasdorp Basin off South Africa. Oil Gas J. 1992, 90, 109-112.

16. Brown, L. Reply to a review of AAPG Studies in Geology no. 41-Sequence stratigraphy in offshore South African divergent basins; an atlas on exploration for cretaceous lowstand traps by Soekor (Pty) Ltd. by Nick Milton, BP Norge. Mar. Pet. Geol. 1997, 14, 469-470. [CrossRef]

17. Jungslager, E.H.A. Geological Evaluation of the Remaining Prospectivity for Oil and Gas of the Pre-1At1 "Synrift" Succession in Block 9, Republic of South Africa; Unpublished Soekor Technical Report SOE-EXP-RPT-0380; 1996; pp. 42-58.

18. McMillan, I.; Brink, G.; Broad, D.; Maier, J. Chapter 13 Late Mesozoic Sedimentary Basins Off the South Coast of South Africa. In Sedimentary Basins of the World; Elsevier BV: Amsterdam, The Netherlands, 1997; pp. 319-376.

19. PGS. Re-Evaluation of the F-A Field and Satellite, Revision; 1999; pp. 46-51. Unpublished.

20. Thomson, K. When did the Falklands rotate? Mar. Pet. Geol. 1998, 15, 723-736. [CrossRef]

21. Sonibare, W.; Sippel, J.; Scheck-Wenderoth, M.; Mikes, D. Crust-scale 3D model of the Western Bredasdorp Basin (Southern South Africa): Data-based insights from combined isostatic and 3D gravity modelling. Basin Res. 2014, 27, 125-151. [CrossRef]

22. Petroleum Agency of South Africa, PASA. Petroleum Exploration Information and Opportunities; Petroleum Agency South Africa Brochure: Cape Town, South Africa, 2003; pp. 1-9.

23. Petroleum Agency of South Africa, PASA. Petroleum Exploration Information and Opportunities; Petroleum Agency South Africa Brochure: Cape Town, South Africa, 2005; pp. 1-8.

24. Petroleum Agency of South Africa, PASA. Petroleum Exploration Information and Opportunities; Petroleum Agency South Africa Brochure: Cape Town, South Africa, 2015; pp. 1-8.

25. Broad, D.; Jungslager, E.; McLachlan, I.; Roux, J.; van der Spuy, D. South Africa's offshore Mesozoic basins. In Regional Geology and Tectonics: Phanerozoic Passive Margins, Cratonic Basins and Global Tectonic Maps; Elsevier: Amsterdam, The Netherlands, 2012; pp. 534-564. [CrossRef]

26. Tinker, J.; de Wit, M.; Brown, R. Linking source and sink: Evaluating the balance between onshore erosion and offshore sediment accumulation since Gondwana break-up, South Africa. Tectonophysis 2008, 455, 94-103. [CrossRef]

27. Akinlua, A.; Sigedle, A.; Buthelezi, T.; Fadipe, O.A. Trace element geochemistry of crude oils and condensates from South African Basins. Mar. Pet. Geol. 2015, 59, 286-293. [CrossRef]

28. Burden, P.L.A.; Davies, C.P.N. Exploration to first production on block 9 off South Africa. Oil Gas J. 1997, 1, 92-98.

29. Powers, M.C. A New Roundness Scale for Sedimentary Particles. J. Sediment. Res. 1953, 23, 117. [CrossRef]

30. Johnson, M.R. Thin section grain size analysis revisited. Sedimentology 1994, 41, 985-999. [CrossRef] 
31. Liu, K.; Greyling, E. Grain-size distribution and cementation of the Cretaceous Mzamba Formation of Eastern Cape, South Africa: A case study of a storm-influenced offshore sequence. Sediment. Geol. 1996, 107, 83-97. [CrossRef]

32. Baiyegunhi, C.; Liu, K.; Gwavava, O. Grain size statistics and depositional pattern of the Ecca Group sandstones, Karoo Supergroup in the Eastern Cape Province, South Africa. Open Geosci. 2017, 9, 554-576. [CrossRef]

33. Wentworth, C.K. Method of Computing Mechanical Composition Types in Sediments. GSA Bull. 1929, 40, 771-790. [CrossRef]

34. McBride, E.F. Diagenetic Processes That Affect Provenance Determinations in Sandstone. In Provenance of Arenites; Springer Science and Business Media LLC: Berlin/Heidelberg, Germany, 1985; pp. 95-113.

35. Folk, R.L. Petrology of Sedimentary Rock; Hemphill Press: Austin, TX, USA, 1974; pp. 103-132.

36. Adams, J. Sieve Size Statistics from Grain Measurement. J. Geol. 1977, 85, 209-227. [CrossRef]

37. Dabbagh, M.E.; Rogers, J.J. Depositional environments, and tectonic significance of the Wajid Sandstone of southern Saudi Arabia. J. Afr. Earth Sci. 1983, 1, 47-57. [CrossRef]

38. Blatt, H. Origin of Sedimentary Rocks. Soil Sci. 1973, 115, 400. [CrossRef]

39. Young, S.W. Petrographic textures of detrital polycrystalline quartz as an aid to interpreting crystalline source rocks. J. Sediment. Petrol. 1976, 46, 595-603.

40. Akarish, A.; El-Gohary, A. Petrography and geochemistry of lower Paleozoic sandstones, East Sinai, Egypt: Implications for provenance and tectonic setting. J. Afr. Earth Sci. 2008, 52, 43-54. [CrossRef]

41. Dott, R.H. Wackes, greywacke and matrix: What approach to immature sandstone classification. J. Sediment. Petrol. 1964, 34, 625-632.

42. Pettijohn, F.J.; Potter, P.E.; Siever, R. Sand and Sandstones; Springer: New York, NY, USA, 1972; pp. 1-49.

43. Pettijohn, F.J.; Potter, P.E.; Siever, R. Sand and Sandstone; Springer Science and Business Media LLC: Berlin/Heidelberg, Germany, 1973; pp. 365-379.

44. Tucker, M.E. Sedimentary Petrology: An Introduction to the Origin of Sedimentary Rocks, 3rd ed.; Blackwell Science Lt: Hoboken, NJ, USA, 2001; pp. 142-165.

45. Raymond, L.A. The Study of Igneous, Sedimentary and Metamorphic Rocks; Wm, C., Ed.; McGraw Hill: New York, NY, USA, 1995; pp. 264-388.

46. Klein, G.D.; Pettijohn, F.J. Sedimentary rocks [book review]. Am. J. Sci. 1976, 276, 766. [CrossRef]

47. Pettijohn, F.J.; Potter, P.E.; Siever, R. Sand and Sandstone; Springer Science and Business Media LLC: Berlin/Heidelberg, Germany, 1987; pp. 431-487.

48. Oghenekome, M.E.; Chatterjee, T.K.; Hammond, N.Q.; van Bever Donker, J.M. Provenance study from petrography of the late Permian e Early Triassic sandstones of the Balfour Formation Karoo Supergroup, South Africa. J. Afr. Earth Sci. 2016, 114, 125-132. [CrossRef]

49. Banerjee, A.; Banerjee, D.M. Modal analysis, and geochemistry of two sandstones of the Bhander Group (Late Neoproterozoic) in parts of the Central Indian Vindhyan basin and their bearing on the provenance and tectonics. J. Earth Syst. Sci. 2010, 119, 825-839. [CrossRef]

50. Baiyegunhi, C.; Liu, K.; Gwavava, O. Modal composition and tectonic provenance of the sandstones of Ecca Group, Karoo Supergroup in the Eastern Cape Province, South Africa. Open Geosci. 2017, 9, 491-508. [CrossRef]

51. Chima, P.; Baiyegunhi, C.; Liu, K.; Gwavava, O. Petrography, modal composition, and tectonic provenance of some selected sandstones from the Stormberg Group, Karoo Supergroup, in the Eastern Cape Province, South Africa. Open Geosci. 2018, 10, 821-833. [CrossRef]

52. Yerino, L.N.; Maynard, J. Petrography of modern marine sands from the Peru-Chile Trench and adjacent areas. Sedimentology 1984, 31, 83-89. [CrossRef]

53. Kumon, F.; Kiminami, K.; Adachi, M.; Bessho, T.; Kusunoki, T.; Mishimura, T.; Okada, H.; Okami, K.; Suzuki, S.; Teraoka, Y. Modal compositions of representative sandstones from the Japanese Islands and their tectonic implications. Mem. Geol. Soc. Jpn. 1992, 38, 385-400.

(C) 2020 by the authors. Licensee MDPI, Basel, Switzerland. This article is an open access article distributed under the terms and conditions of the Creative Commons Attribution (CC BY) license (http://creativecommons.org/licenses/by/4.0/). 